\title{
In-house R\&D, external R\&D and cooperation breadth in Spanish manufacturing firms: is there a synergistic effect on innovation outputs?
}

Dragana Radicic, Lincoln International Business School, University of Lincoln, UK Merima Balavac, Department for Quantitative Economics, School of Economics and Business, University of Sarajevo, B\&H

\begin{abstract}
This study explores the nature of relationship between in-house $R \& D$, external $R \& D$ and cooperation breadth and their joint impact on patent counts as well as technological, product and process, innovations in Spanish manufacturing firms. With regards to patent counts, empirical findings from a Generalised Method of Moments (GMM) estimator suggest a complementarity effect of internal and external R\&D activities conditional on the breadth of R\&D cooperation. Concerning technological innovation, results from dynamic random-effects probit models indicate no synergistic effects. In addition, we find evidence of persistence of all three innovation output measures. Our results suggest policy implications in relation to strengthening firms' absorptive capacity that could have long-run effects.
\end{abstract}

Keywords: Internal and external R\&D; Cooperation breadth; Complementarity; Dynamic panel analysis; Spanish manufacturing

JEL codes: O31, O32, O38, Q55 


\section{Introduction}

With the prevalence of the open innovation mode in firms, an increasing number of studies explores the relationship between internal and external innovation activities and their impact on innovation and firm performance. Our study examines the joint impact of internal and external $\mathrm{R} \& \mathrm{D}$ expenditures on innovation performance depending on the number of cooperative partners (termed cooperation breadth, Laursen and Salter, 2006). Innovation activities are not limited to internal $R \& D$, but firms rather expend their innovation capacity by opening up innovation processes through $R \& D$ outsourcing, licensing, cooperation for $R \& D$ and innovation, or company acquisition (Berchicci, 2013; Cassiman and Veugelers, 2006; Chesbrough, 2003; Schmiedeberg, 2008; Van de Vrande et al., 2009). Opening up of innovation processes raises a question whether internal and external innovation activities have a joint performance effect by either being complements or substitutes. Modification and expansion of firms' resource base through acquiring and assimilating external knowledge is associated with the concept of absorptive capacity (Cohen and Levinthal, 1989). Higher absorptive capacity is the key driver of complementarity between R\&D activities (Choi et al., 2012), which arises when an increase in one innovation activity leads to an increase in marginal returns of another innovation activity (Cassiman and Veugelers, 2006; Hagedoorn and Wang, 2012; Schmiedeberg, 2008). Contrastingly, internal and external R\&D activities might be substitutes, when an increase in one innovation activity leads to a reduction in marginal returns of another innovation activity (Hagedoorn and Wang, 2012).

Theoretical arguments for both complementarity and substitutability have been put forward. Transaction cost economics suggests that internal and external knowledge acquisition are substitutes (Cassiman and Veugelers, 2006; Pisano, 1990). Contrary to transaction costs economics, other theoretical frameworks, such as the open innovation paradigm (Chesbrough, 2003), the resource-based view of the firm (Barney, 1991), the relational view of the firm (Dyer and Singh, 1998) and the knowledge-based view of the firm (Kogut and Zander, 1992) consider internal and external knowledge sources as complementary activities. Absorptive capacity, defined as a modification and expansion of firms' resource base through acquiring and 
assimilating external knowledge Cohen and Levinthal, 1989) is regarded as the key driver of complementarity between R\&D activities (Choi et al., 2012).

Concerning empirical evidence, the largest number of empirical studies explores complementarity between internal and external R\&D activities (e.g. Arvanitis et al., 2015; Berchicci, 2013; Cassiman and Veugelers, 2006; Grimpe and Kaiser, 2010; Schmiedeberg, 2008). Only recently researchers start examining complementarity between different external knowledge strategies (see e.g. Arvanitis et al., 2015) or between internal R\&D activities and R\&D cooperation (see e.g. Berchicci, 2013; Ebersberger and Herstad, 2011; Grimpe and Kaiser, 2010; Vega-Jurado et al., 2008).

This study is based on panel data of Spanish manufacturing firms, covering the period from 2001 to 2014. The first contribution of the study is the analysis of three-way interaction between internal $R \& D$, external $R \& D$ and cooperation breadth. To our knowledge, only two studies (Arvanitis et al., 2015; Seranno-Bedia et al., 2012) model three-way interactions between these innovation activities. Our contribution is in particular related to a detailed analysis of the effects stemming from three-way interactions. The isolation of these effects of $R \& D$ inputs on innovation outputs at different levels of cooperation allows us to investigate the potential differences in their contribution conditional on cooperation breadth.

The second contribution is in relation to the measures of innovation outputs. Our measures of innovation performance encompass three types of innovation output: a) patent counts (as a measure of an intermediate innovation output), b) introduction of product innovation, and c) introduction of process innovations. Measures of technological innovations are less utilized in this stream of research than other innovation output measures, such as patent applications and innovative sales. Moreover, few studies (e.g. Krzeminska and Eckert, 2016) report empirical evidence for process innovation. The investigation of all three innovation output indicators enables us to compare and contrast findings on the joint impact of innovation activities on each indicator. We discuss potential reasons for the complementarity/substitutability effects of internal and external R\&D activities on patent counts, product and process innovations, and we also conceptualise differences in the effects depending on the number of partners with whom firms establish cooperative ties.

The third contribution is associated with measuring both internal and external R\&D activities as continuous variables, rather than binary indicators, which is a common practice in empirical studies in this stream of research. This measurement strategy enabling us to take into account the scale of innovation activities and not only whether firms engage in these activities. Moreover, $R \& D$ cooperation is operationalized as the cooperation breadth, that is, the number 
of partners that cooperate with a focal firm (customers, suppliers, competitors, universities, and joint ventures). In investigating complementarity between innovation activities, we control for both economies of scale and economies of scope, and thus model the non-linearity in internal R\&D activities and external knowledge strategies, i.e. external $R \& D$ and cooperation (Arvanitis et al., 2015; Ebersberger and Herstad, 2011; Pippel and Seefeld, 2016).

Finally, the fourth contribution is associated with persistence of innovation. Namely, innovation can be path and/or past dependent, and accordingly, the literature distinguishes between true or genuine state dependence and spurious one (Raymond et al., 2010). In this study, although not as a primary focus, we take into account that innovation outcomes (patent counts, product and process innovations) could be persistent over time. In this respect, this is among first studies to combine insights from two streams of research: i) a joint impact of innovation inputs (i.e. potential complementary effects) on innovation performance; and ii) persistence of innovation.

This study is organized as follows. The next chapter reviews theoretical and empirical literature on innovation activities and their impact on innovation performance. The review is then followed by the description of the dataset and its summary statistics. The next section discusses model specification and empirical strategy employed in the study. Then, we present and discuss our empirical findings. Finally, the paper concludes with managerial and policy implications, as well as limitations of the study and suggestions for further research.

\section{Literature review and hypotheses development}

Whether innovation activities yield complementary or substituting effects is a subject of several theoretical frameworks. Transaction cost economics emphasizes a substituting effect between "make" and "buy" strategies (i.e. internal and external knowledge acquisition) (Cassiman and Veugelers, 2006; Pisano, 1990; Williamson, 1985). Namely, firms will choose whether to produce internally or acquire externally conditional on the extent of transaction costs (those of negotiating, controlling and enforcing contracts). That is, internal production is an optimal governance structure if results in lower transaction costs. Otherwise, "buy" strategy should be pursued.

Other theoretical frameworks suggest a complementary effect. The open innovation paradigm reignited the attention of scholars, managers and policy makers to external search, acquisition and assimilation of knowledge. In this framework, external innovation activities are equally relevant as internal innovation (Schmiedeberg, 2008). Following the knowledge-based 
view of the firm (Kogut and Zander, 1992), firms' innovation capacity can be enhanced through a simultaneous engagement in both in-house innovation as well as external knowledge sourcing. In addition, the relational-based view of the firm (Dyer and Singh, 1998) suggests that inter-firm cooperation and R\&D outsourcing increase the likelihood of new product development. This perspective pays a particular attention to the role of trust and long-term relations in enhancing innovation and firm performance. Finally, according to the resourcebased view of the firm, outsourcing $R \& D$ enables firms to gain comparative advantage, when the former is combined with firms' internal resources (Barney, 1991). Technology outsourcing can enable firms to tap into resources that are not available within the firm (Grimpe and Kaiser, 2010).

Grimpe and Kaiser (2010) review potential benefits and pitfalls of outsourcing R\&D. The former encompasses the cost and time reduction and cost sharing between the firm and the contractor. Additionally, the contractor may provide tacit knowledge and physical assets that are specifically relevant for the contracted $R \& D$ activity. Finally, outsourcing R\&D can enhance firms' internal $\mathrm{R} \& \mathrm{D}$, through knowledge transfer, facilitating creativity and mitigating internal resistance to innovation.

However, outsourcing R\&D can entail some drawbacks. Difficulties can arise in defining and agreeing upon Intellectual Property Rights (IPRs). Moreover, hiring an external firm to conduct R\&D can cause the "not-invented-here" (NIH) syndrome, whereby employees in the focal firm reject externally generated knowledge to the likely detriment of the firm's performance (Grimpe and Kaiser, 2010; Katz and Allen, 1982). In addition, Grimpe and Kaiser (2010) identify three sources of potential diseconomies of scale in external R\&D activities due to limited absorptive capacity. First, firms' internal resources can be diluted (thus, more prone to imitation by competing firms) as a consequence of over-reliance on external knowledge sources. Second, firms' integrative capabilities could be adversely affected by excessive outsourcing. Integrative capabilities are defined as "an adhesive by absorbing critical knowledge from external sources and by blending different technical competencies developed in various company departments" (Verona, 1999, p.134). In turn, over-reliance on external sourcing can be detrimental to firms' innovation performance because of difficulties in transferring tacit knowledge. That is, unlike codified knowledge, tacit knowledge is often more difficult to exchange from the $R \& D$ contractor to the client firm, because of its intangible nature (Weigelt, 2009). A large component of R\&D outsourcing, and R\&D activities in general, is tacit knowledge, embedded, for example, in the expertise of R\&D personnel (Sapienza and 
Lombardino, 2002). Finally, management attention is a limited resource and its limited availability can lead to 'over-outsourcing' R\&D.

Besides benefits and pitfalls that each individual, internal and external, innovation activity can bring about to firms' innovation performance, they can also induce synergistic (complementary or substituting) innovation effects. Accordingly, complementarity between internal and external $R \& D$ activities occurs when an increase in one $R \& D$ activity increases a marginal return to another R\&D activity (Cassiman and Veugelers, 2006; Hagedoorn and Wang, 2012; Schmiedeberg, 2008). The key mechanism in explaining complementarity between internal and external R\&D activities is absorptive capacity (Hagedoorn and Wang, 2012; Woerter, 2011). Absorptive capacity, defined as firms' ability to explore and utilize external knowledge (Cohen and Levithal, 1990), implies that firms do not innovate in isolation, exploiting solely their own, internal R\&D and innovation capacity (Cassiman and Veugelers, 2006; Grimpe and Kaiser, 2010). Rather, firms adopt an open innovation mode (Chesbrough, 2003) by searching and assimilating knowledge outside of boundaries of the firm. Therefore, the extent of absorption of external knowledge critically depends on firms' internal R\&D capacity, and more broadly, on their absorptive capacity. In addition, the more external knowledge the firm is capable to exploit, the larger absorptive capacity. Therefore, internal and external R\&D activities are mutually reinforcing via firms' absorptive capacity. ${ }^{1}$ Another benefit of complementarity between innovation activities, besides enhancing absorptive capacity, is that it might entail economies of scope, given that through outsourcing, firms share research infrastructure and $R \& D$ personnel, and thus achieve cost reduction (Krzeminska and Eckert, 2015). Finally, complementarity between innovation activities could incur incoming knowledge spillovers, defined as the amount of exploitable external knowledge that flows into the focal firm (Arvanitis et al., 2015; Krzeminska and Eckert, 2015).

In contrast, a substituting effect implies that an increase in one activity reduces a marginal return on another activity. Theoretical rationales for potential substitutability between innovation activities are related to switching costs and/or diseconomies of scope (Hagedoorn and Wang, 2012; Hess and Rothaermel, 2011; Rothaermel and Hess, 2007). The former arises because of path dependence within innovation processes. If a firm develops skills and capabilities in undertaking one type of innovation, then switching to another type of innovation could incur high switching costs. Consequently, a joint implementation of different innovation

\footnotetext{
${ }^{1}$ Technological capabilities are considered an important component of absorptive capacity, and a key driver in a successful introduction of product innovation (Moorman and Slotegraaf, 1999; Wu, 2014).
} 
activities might result in a decrease in marginal returns to innovation (Hagedoorn and Wang, 2012; Rothaermel and Hess, 2007). Another cause of a substituting effect, as mentioned above, is the presence of diseconomies of scope in internal and external $\mathrm{R} \& \mathrm{D}$, such that simultaneously undertaking both activities results in similar outcomes (Hagedoorn and Wang, 2012; Hess and Rothaermel 2011). Conversely, economies of scope can occur as a result of a simultaneous use of production inputs, such as research facilities and personnel, for several innovation activities (Schmiedeberg, 2008). Specifically, economies of scope arise due to knowledge spillovers from intrafirm and interfirm R\&D projects, or even due to intertemporal spillovers, that occur when knowledge accumulated in past $R \& D$ project influences current $R \& D$ activities (Schmiedeberg, 2008). Besides switching costs and diseconomies of scope, there are other potential sources of substitutability between innovation activities. First, acquiring knowledge and technology through outsourcing could lead to the opportunistic behaviour of other firms (Arvanitis et al., 2015; Krzeminska and Eckert, 2015). Here, the role of intellectual property rights (IPRs) is critical, such that firms need to protect their innovation and keep outgoing knowledge spillovers under its control (Arvanitis et al., 2015). Second, employees might resist the acquisition of knowledge that is externally sourced, either by simply rejecting external ideas or under-utilizing external knowledge sources. This is known as the not-invented-here (NIH) syndrome (Katz and Allen 1982; Krzeminska and Eckert, 2015). Finally, firms might face problems with coordination and communication of external knowledge (Berchicci, 2013; Krzeminska and Eckert, 2015). In summing up, the key question is whether benefits of external knowledge sourcing outweigh its costs. Here the theory does not provide a clear-cut answer (Krzeminska and Eckert, 2015). Consequently, interrelationships between innovation inputs and their synergistic effects on firms' innovation performance are predominantly an empirical issue and context specific (Cassiman and Veugelers, 2006).

After discussing the causes of potential synergistic effects of internal and external R\&D activities, we turn our attention to the occurrence of joint effects among different innovation output indicators. Regarding patenting activities, the impact of R\&D may be underestimated in previous empirical studies, as a development phase, which is usually a larger portion of $R \& D$ expenditure, does not contribute to patent application (Czarnitzki et al., 2009; Grilliches, 1990). Concerning technological innovation, the difference in a potential complementarity between external and internal R\&D activities might arise due to different characteristics of knowledge required for product and process innovations. With respect to process innovation, the theory does not provide a clear-cut answer whether interrelations between innovation activities and their synergistic effects are different than for product innovation (Krzeminska and Eckert, 
2015). On the one hand, firms are less likely to reap any of the benefits of complementarity between internal and external knowledge source in the case of process innovation relative to product innovation because of the nature of knowledge embedded in process innovation. Namely, this knowledge is tacit, systemic and idiosyncratic, and these characteristics critically affect the degree of absorptive capacity and the degree of economies of scope and knowledge spillovers arising from complementary interrelations between internal and external knowledge sources. More specifically, process innovation should require a higher absorptive capacity than product innovation, because knowledge embedded in process innovation is likely to be idiosyncratic to the firm and systematically connected with other firm activities, thus making the transfer and accumulation of knowledge difficult for the focal firm (Krzeminska and Eckert, 2015). Moreover, the specific characteristics of knowledge involved in process innovation (tacitness, idiosyncrasy and a systematic nature) decrease the potential for cost reductions through economies of scope and benefits from knowledge spillovers.

Looking at the arguments against complementarity and their application in the context of process innovation (Krzeminska and Eckert, 2015) argue that they are less pronounced than in the case of product innovation. The main argument is associated with a lower probability of opportunistic behaviour of other firms, as knowledge embedded in process innovation is difficult for other firms to imitate due to its tacitness, idiosyncrasy and a systematic nature. In summing up, arguments brought forward in favour of complementarity of internal and external knowledge sources are less pronounced in case of process innovation than product innovation, but at the same time, arguments against complementarity and in favour substitutability are also less pronounced for process than product innovation. Therefore, the interrelations between internal and external knowledge sources and their synergistic effects on process innovations remains to be an empirical issue, which is the same conclusion as drawn above for any other type of innovation output.

Besides a potential joint impact of internal and external R\&D activities, another source of innovative activities is collaboration for innovation. Firms collaborate with a number of different partners, such as customers, suppliers, competitors, universities, public agencies etc. (Ebersberger and Herstad, 2011). Motives for cooperation vary conditional on the type of partner. Accordingly, cooperation with customers is aimed at utilizing complementary resources and knowledge and mitigating market uncertainty (Ebersberger and Herstad, 2011), while cooperation with suppliers provides production inputs tailored to the needs of the focal firm (Ebersberger and Herstad, 2011). Cooperation with universities and research institutes enables firms to tap into new knowledge from fundamental research (Ebersberger and Herstad, 
2011; Un et al., 2010). Firms cooperate with competitors to share R\&D costs and/or to combine resources in a complementary manner (Un et al., 2010). Cooperation with competitors, however, can yield sub-optimal results due to opportunistic behaviour, knowledge leakage or the lack of trust between firms (Nieto and Santamaría, 2007; Ritala and HurmelinnaLaukkanen, 2009; Selnes and Sallis, 2003; Wu, 2014).

Cooperation and R\&D outsourcing are both external knowledge sources. With respect to differences between them, firms engage in $R \& D$ outsourcing if they have limited resources and pursue low-risk and low-cost knowledge exchange. More specifically, transaction costs related to $R \& D$ outsourcing are significantly lower than in the case of cooperation, because asset specificity is low and the opportunities behaviour of a partner firm as well as coordination and communication issues are unlikely occur because the interdependence between firms is minimal (Gimenez-Fernandez and Sandulli, 2017). Likewise, R\&D outsourcing enables firms to access new technologies with more flexibility and less investment in organizational resources than in the case of cooperation (Ebersberger and Herstad, 2011). In contrast, cooperation for innovation entails higher transaction costs than $R \& D$ outsourcing, but this is counterbalanced with a higher degree of learning and of asset specificity. Namely, whereas R\&D outsourcing entails a transfer of explicit knowledge embodied in documents and physical capital, cooperation for innovation involves knowledge exchange which is more complex and tacit (Gimenez-Fernandez and Sandulli, 2017; Ebersberger and Herstad, 2011). Furthermore, following Grimpe and Kaiser (2010), cooperation might mitigate the negative effects of overoutsourcing (discussed above), such that extending a cooperative network increases the likelihood that the focal firm will access novel and unique knowledge (Gimenez-Fernandez and Sandulli, 2017).

After discussing theoretical arguments in favour of complementary/substituting effects, Table A1 in the Appendix presents an overview of the previous empirical findings on all three relationships: i) between internal and external $R \& D$; ii) between internal $R \& D$ and cooperation; and iii) between external $R \& D$ and cooperation, and their complementary/substituting impacts on various innovation output indicators. Concerning the first relation between internal and external $R \& D$ and their impact on patenting, empirical evidence suggests either complementary effects (Beneito, 2006), mixed effects (substitutes below 1,400 million US dollars and complements above the threshold; Hagedoorn and Wang, 2012) or insignificant effects (Schmiedeberg, 2008). Among few studies examining product innovation, Vega-Jurado et al. (2009) investigate the joint impact of internal and external R\&D 
activities on product innovation in Spanish firms and report an insignificant joint effect. In contrast, Antonelli and Fassio (2016) report complementary effects on product innovation in Belgium, Czech Republic, Germany, Italy, Norway and Spain. Process innovation is the least investigated type of innovation output in this stream of research (Krzeminska and Eckert, 2016). While Antonelli and Fassio (2016) report complementary effects of internal and external R\&D activities on process innovation, Krzeminska and Eckert (2016) find insignificant synergistic effects. Finally, in relation to innovative sales, as the most frequently investigated output indicator, empirical findings mostly point out to a complementary effect (Berchicci, 2013; Cassiman and Veugelers, 2006; Grimpe and Kaiser, 2010; Krzeminska and Eckert, 2016; Serrano-Bedia et al., 2012), and to a lesser degree insignificant effect (Choi et al., 2012; Schmiedeberg, 2008). The review of empirical evidence in Table A1 suggests that complementarity between R\&D activities is often found for innovative sales, but not for product innovation. This pattern might indicate that complementary effects are more pronounced in the commercialization phase of the innovation process, rather than in the phase of developing technological innovations. In other words, the joint impact of internal and external R\&D activities could vary depending on the stage of the innovation process. In the development stage, firms might need to protect themselves from a potential opportunistic behaviour of their partners or might incur high transaction costs arising from introducing product and process innovations through external technology sourcing. Consequently, costs of outsourcing could offset its benefits (Grimpe and Kaiser, 2010). In the commercialization stage, however, these negative effects of outsourcing are less likely to occur.

With respect to the second type of relationship - between internal R\&D and cooperation- overall empirical evidence again is inconclusive. Only Schmiedeberg (2008) reports their joint impact on patenting and finds a complementary effect. With respect to product innovation, complementarity is reported in Vega-Jurado et al. (2008) and Ebersberger and Herstad (2011), substitution in Vega-Jurado et al. (2008) and Serrano-Bedia et al. (2018); and Ebersberger and Herstad (2011), and an insignificant effect in Vega-Jurado et al. (2008; 2009). Concerning Spanish firms, Vega-Jurado et al. (2008) found a substituting effect of internal R\&D and cooperation with non-industry agents (HEIs, consultants, public research organisations, and commercial labs) on product innovation, but no effect of in-house R\&D and cooperation with industry agents (customers, suppliers, competitors and firms from the same enterprise group). Similarly, Vega-Jurado et al. (2009) report an insignificant joint effect of inhouse $R \& D$ and cooperation on product innovation. Empirical studies investigating synergistic effects on process innovation are scarce, as mentioned above. Serrano-Bedia et al. (2018) find 
a substituting effect between internal knowledge sources and cooperation on process innovation in Spanish firms. The only study using innovative sales as a measure of innovation outputs is conducted in the context of Chinese Zheijang province (Chen et al., 2016). They find complementarity effects between internal $R \& D$ and value-chain partners; between internal $\mathrm{R} \& \mathrm{D}$ and horizontal cooperative partners; and between internal R\&D and technology service providers.

Finally, empirical evidence in relation to the third type of interrelationship, those between external $R \& D$ and cooperation, is scarce. As with other interrelationships, results are mixed (see Table A1 in the Appendix). Concerning product innovation, Ebersberger and Herstad (2011) explore complementarity between external R\&D and cooperation in a crosssection sample of Norwegian firms. They report a substituting effect of external R\&D and collaboration breadth on the introduction of product innovation. Relatively more studies utilize innovative sales as a measure of the commercial success of product and/or process innovation and report both types of effects - complementarity (Grimpe and Kaiser, 2010); and substitution (Choi et al, 2012).

Finally, our main focus is on empirical findings from studies that explore the three-way interactions between internal $R \& D$, external $R \& D$ and cooperation. Here, empirical evidence is particularly scarce. Namely, only two studies investigate three-way interactions between internal $R \& D$, external $R \& D$ and cooperation and both utilize innovative sales as a measure of innovation performance, which means that they are not directly comparable to our results, because our data does not contain information on innovative sales. First, Arvanitis et al. (2015) investigate complementarity between cooperation and external $R \& D$ expenditure in a panel of Swiss and Dutch manufacturing and service firms. They apply a static random-effects panel model and take into account non-linearities in firms' cooperative activities as well as in internal and external R\&D activities. Their findings suggest complementarity effect of all three innovation activities in the Dutch firms, whereas no significant relationships are found in Swiss counterparts. Second, Serrano-Bedia et al. (2012) found a complementary effect of all three innovation activities on innovative sales in the cross-sectional analysis of Spanish firms. ${ }^{2}$

The conclusion from the empirical literature review presented in Table A1 is consistent with Schmiedeberg (2008) and Serrano-Bedia et al. (2018), who argue that empirical evidence on complementarity between innovation activities is mixed and conditional on countries

\footnotetext{
${ }^{2}$ However, these studies only report coefficients on the three-way interactions, while marginal effects are neither reported nor interpreted.
} 
analysed, empirical methods utilized, variations in model specifications and measurements of innovation input and output indicators. Therefore, given that both theory and empirical work are inconclusive in suggesting whether the joint impact of innovation activities will have a complementary or a substituting effect on innovation outputs and as there is no previous empirical evidence on the three-way interactions using innovation output indicators as in our study, we formulate the following hypotheses.

Hla: Internal and external $R \& D$ have a complementary effect on patent counts moderated by the breadth of $R \& D$ cooperation.

HIb: Internal and external $R \& D$ have a substituting effect on patent counts moderated by the breadth of $R \& D$ cooperation.

H2a: Internal and external $R \& D$ have a complementary effect on the introduction of product innovation moderated by the breadth of $R \& D$ cooperation.

$H 2 b$ : Internal and external $R \& D$ have a substituting effect on the introduction of product innovation moderated by the breadth of $R \& D$ cooperation.

H3a: Internal and external $R \& D$ have a complementary effect on the introduction of process innovation conditional on the breadth of $R \& D$ cooperation.

$H 3 b$ : Internal and external $R \& D$ have a substituting effect on the introduction of process innovation conditional on the breadth of $R \& D$ cooperation.

\section{Methodology}

To test for complementarity/substitutability between two or more activities, three approaches can be utilized (Barge-Gil and López, 2013): the correlation approach (e.g. Schmiedeberg, 2008); the adoption or indirect approach (e.g. Cassiman and Veugelers, 2006); and the production or direct approach (e.g. Berchicci, 2013; Cassiman and Veugelers, 2006; Grimpe and Kaiser, 2010; Hagedoorn and Wang, 2012; Lokshin et al., 2008; Schmiedeberg, 2008).

The first approach cannot satisfy both necessary and sufficient conditions for the existence of complementarity (computing unconditional or conditional correlation coefficients does not allow for controlling for unobserved heterogeneity) (Cassiman and Veugelers, 2006; Hagedoorn and Wang, 2012; Schmiedeberg, 2008). The second approach, based on the estimation of the reduced form equation with exclusion restrictions (Barge-Gil and López, 2013), is usually employed when the main objective is to reveal the causes of 
complementarity/substitutability (Cassiman and Veugelers, 2006), which is not the focus of this study. ${ }^{3}$ Hence, we employ the third (production) approach.

The production approach allows for testing for complementarity/substitutability by estimating the equation of interest and including the interaction terms between innovation activities. This approach could be more effective than correlation approach to indicate the efficiency of a joint implementation of innovation strategies (Arvanitis et al., 2015). A complementarity/substitutability, in the context of this study, is tested by the inclusion of the three-way interaction term between internal $R \& D$, external $R \& D$ and the cooperation breadth. This type of analysis is utilized when the activities of interest are measured as continuous variables, whereas in the case when innovation activities are captured with binary indicators, an appropriate analysis encompasses testing for inequality in restrictions (after estimating a model with the interaction term). The latter is based on the theory on supermodularity, first proposed by Topkis (1978) and later developed by Milgrom and Roberts (1995) (Barge-Gil and López, 2013; Schmiedeberg, 2008).

Although the theory and empirical work indicate diseconomies of scale in R\&D, Lokshin et al. (2008) note that the quadratic term necessary for testing for (dis)economies of scale is often omitted in empirical work, because of the problem with multicollinearity between the linear and quadratic terms. Furthermore, they argue that a panel data analysis does not solve, but at least reduces the problem of multicollinearity, and this argument is adopted in our analysis as well. Moreover, according to Lokshin et al. (2008), firms would be inclined to combine both innovation activities (internal and external R\&D) particularly when diseconomies of scale in internal and external R\&D are pertinent to the innovation process. Therefore, to take into account the possibilities of both (dis)economies of scale and (dis)economies of scope, we need to include quadratic terms on internal $R \& D$, external $R \& D$ activities and cooperation breadth, as well their interaction terms, because "empirical studies combining complementarities between continuously measured practices should adopt more general nonlinear specifications to allow for correct inferences" (Lokshin et al., 2008, p. 419).

\section{Data}

The dataset used in the study is the Spanish Business Strategies Survey (SBSS). This is a longitudinal survey conducted annually from 1990 and covering all manufacturing sectors in

\footnotetext{
${ }^{3}$ The correlation between error terms in, for instance, bivariate and multivariate categorical models is interpreted as an evidence of complementarity (Schmiedeberg, 2008).
} 
Spain based on NACE-Rev.1 classification (Santamaría et al., 2009). The data is gathered by the Public Enterprise Foundation and sponsored by the Spanish Ministry of Industry (Diaz and Sanchez, 2008; Santamaría et al., 2009). ${ }^{4}$ Although the purpose of the survey is not only to gather information regarding firms' innovation activities, but also about firms' performance and characteristics in general (Santamaría et al., 2009), many studies used the SBSS data to analyse innovation-related research questions (e.g. Cassiman et al., 2010; Cruz-Cázares et al., 2013; Gonzáles and Pazó, 2008; Gonzáles et al., 2005; Diaz and Sanchez, 2008; Montoya et al., 2007; Santamaría et al., 2009). The sample is representative of Spanish manufacturing firms, whereby the sampling methodology is contingent on firm size (Cruz-Cázares et al., 2013; Diaz and Sanchez, 2008; Montoya et al., 2007; Santamaría et al., 2009). That is, firms with more than 10 and less than 200 employees are selected based on a random stratified sample, while all firms with more than 200 employees are included in the survey in the initial year (Diaz and Sanchez, 2008; Montoya et al., 2007; Santamaría et al., 2009). Those firms that exit the sample for various reasons are replaced by newly established firms, using the same sampling procedure as in the initial, 1990 year (Diaz and Sanchez, 2008; Montoya et al., 2007). The data are skewed towards small and medium-sized enterprises (SMEs), for instance, the sample in Diaz and Sanchez (2008) comprises of $72.1 \%$ firms with more than 10 and less than 200 employees. ${ }^{5}$

Our sample is an unbalanced panel covering the period from 2001 to 2011, thus excluding the period from 1990-2000, partly because information on external sources of innovation and more detailed information on innovation activities were first introduced in the 1998 survey (Santamaría et al., 2009). In addition, following previous studies (Cassiman and Veugelers, 2006; Grimpe and Kaiser, 2010; Krzeminska and Eckert, 2016; Schmiedeberg, 2008), our sample is restricted to innovative firms, i.e. firms that reported either internal or external R\&D expenditures, because our dependent variables measure innovation output indicators. Consequently, after excluding non-innovating firms and removing observations with missing values, our effective samples are reduced to 7,595 firm-year observations in Model 1 with the patent counts as the dependent variable); 7,604 firm-year observations in Model 2 with production innovation as the dependent variable; and 7,604 firm-year observations in Model 3 with process innovation as the dependent variable.

Table A2 in the Appendix shows variable description and descriptive statistics. In the longitudinal sample of Spanish firms in the period 2001-2011, 44.3 per cent of firms introduced

\footnotetext{
${ }^{4}$ For more information, see https://www.fundacionsepi.es/

${ }^{5}$ The SME definition by the European Commission is slightly different, using the headcount of 250 employees as an upper bound.
} 
product innovation, while slightly more than half (52.5 per cent) of firms engage in process innovation. Firms, on average, apply for one patent a year. Regarding innovation activities, on average, firms invest 39,262 Euros in internal R\&D and 2,280 Euros in external R\&D. With respect to the number of cooperative ties, firms collaborate on innovation with three partners on average. More than a half of firms have a formal R\&D department ( 60.5 per cent). The share of export in sales is on average 82.6 per cent. Less than half of firms (40.2 per cent) participates in technologically innovative firms. A modal firm has 193 employees, while the average market share is 13.8 per cent. The average firm age is 39 years. Finally, the average share of foreign capital is 29.43 per cent.

\section{Model specification}

Equation (1) below shows three models for testing formulated hypotheses on substitutability between internal and external R\&D activities conditional on the cooperation breadth.

$$
\begin{aligned}
& \text { Dependent variable }_{i, t}=\beta_{0}+\beta_{1} \text { Dependent }_{\text {variable }} \text { vet }-1_{1}+\beta_{2}{\text { Internal } R \& D_{i, t-1}+}+ \\
& \beta_{3} \text { Internal } R \& D_{i, t-1}^{2}+\beta_{4} \text { External } R \& D_{i . t-1}+\beta_{5} \text { External } R \& D_{i, t-1}^{2}+\beta_{6} \operatorname{Coop}_{i . t-1}+ \\
& \beta_{7} \text { Coop }_{i, t-1}^{2}+\beta_{8}\left(\text { Internal } R \& D_{i, t-1} * \text { External } R \& D_{i, t-1}\right)+\beta_{9}\left(\text { Internal } R \& D_{i, t-1} *\right.
\end{aligned}
$$

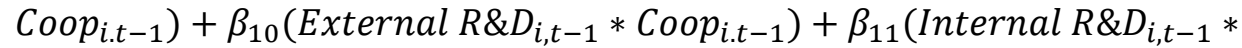

$$
\begin{aligned}
& \text { External } \left.R \& D_{i, t-1} * \text { Coop }_{i . t-1}\right)+\beta_{12} \text { Export }_{i, t}+\beta_{13} \text { Size }_{i, t}+\beta_{14} \text { Market share }_{i, t}+ \\
& \beta_{15} \text { Participation }_{i, t}+\beta_{16} \text { Age }_{i, t}+\beta_{17} R \& D \text { department }_{i, t}+\beta_{18} \text { Foreign capital }_{i, t}+ \\
& \beta_{j} \text { Industry }_{j, t}+\beta_{k} \text { Year }_{k, t}+u_{i}+\varepsilon_{i, t}
\end{aligned}
$$

Where subscript $i$ indexes each firm in the sample $(i=1, \ldots, n$, where $n$ is the number of firms); subscript $t$ indexed the time period $(t=1, \ldots, 2011)$; the $\beta$ coefficients measure the effects of independent variables; $u_{i}$ denotes the firm-specific unobservable effect and $\varepsilon_{i, t}$ is a random error.

The three dependent variables are: patent counts (Model 1); a binary indicator for the introduction of product innovation (Model 2); and a binary indicator for the introduction of process innovation (Model 3). These dependent variables capture innovation output indicators. Patenting activities of the firm are measured as the number of patent applications in Spain and abroad (Patents) (see e.g. Vega-Jurado et al., 2009). Patent counts (applications) is a preferred output indicator rather than the value of individual patents which is characterized by the large variance and stochastic elements (Griliches et al., 1987). However, patent counts are not free of criticism. The literature argues that not all innovations are patentable nor not all patentable innovations are patented, and that those that are patented might considerably differ in terms of 
quality (Beneito, 2006). As an illustration, process innovation is patented to a less extent than product innovation (Rodriguez-Pose and Di Cataldo, 2015). Because of these limitations in using patents as an innovation output indicator and to take into account technological aspects of innovation activities, two alternative indicators of innovation outputs are utilised: Product innovation (a binary indicator equal to 1 if a firm introduced process innovation; zero otherwise) and Process innovation (a binary indicator equal to 1 if a firm introduced process innovation; zero otherwise). Differences between product and process innovations are conditional on the type of knowledge embedded during the innovation process (Gopalakrishnan et al., 1999, 2003; Reichstein and Salter, 2006; Wong et al., 2008). Namely, tacit knowledge is more associated with process than with product innovations, as the latter is the integral part of the product and may be observed more easily (Cohen and Klepper, 1996; Gopalakrishnan et al., 1999). Unlike codified knowledge, tacit knowledge is often more difficult to exchange from $R \& D$ contractor to a client firm, due to its intangible nature (Weigelt, 2009). Furthermore, process innovations absorb knowledge more intensively from other subsystems of the organizations (Ettlie and Reza, 1992), while product innovations are often the result of a rather independent team work (Fang et al., 2010).

All three models have the same set of independent variables. Variable Internal $R \& D$ is a continuous variable capturing internal $R \& D$ expenditures (in natural logarithm). In-house R\&D activities are regarded as a proxy for absorptive capacity of the firm (Beneito, 2006). We use $R \& D$ expenditure instead of $R \& D$ intensity to avoid uncertainty related to the latter. Namely, when R\&D expenditure is divided by firm revenues, it is unclear whether the observed effect stems from the numerator or the denominator (Hagedoorn and Wang, 2012; Rothaermel and Hess, 2007). Similarly, external R\&D expenditures (External RD) measures a volume of external R\&D expenditure (in natural logarithm) (see e.g. Arvanitis et al., 2015). The variable Coop measures the breadth of cooperative activities, i.e. the number of firms' cooperative ties (Arvanitis et al., 2015; Ebersberger et al., 2012; Laursen and Salter, 2006). A number of partners varies from zero (if a firm does not cooperate with any of the five partners) to five (if a firm cooperates with customers, suppliers, competitors, HEIs and participates in joint ventures).

Other firm and market characteristics included in the models are as follows. To take into account internationalization and its effect on innovation, the variable Export is measured as a ratio of exports scaled by sales (Czarnitzki and Lopes-Bento, 2013; Schmiedeberg, 2008). Firm size (Size) is measured by the number of employees (in natural logarithm) (see e.g. Berchicci, 2013; Vega-Jurado et al., 2008). The effect of competition is proxied by the variable 
Market share measured as the weighted sum of the firms' market shares in all the markets in which the firms sell their products. A measure of firms' internal R\&D capacity is the establishment of a separate $\mathrm{R} \& \mathrm{D}$ department ( $R \& D$ department) equal to 1 if the firm has a separate $R \& D$ department, and zero otherwise. Firm age is also included in the model as a variable Age (in natural logarithm) (see e.g. Berchicci, 2013). Another firm characteristic that is controlled in the model is the participation of foreign capital in a firm' total capital (in percentages, variable Foreign capital). To account for participation in technologically innovative firms, the model includes a binary variable Participation, which is equal to 1 if firms participate in technologically innovative firms and zero otherwise. This variable captures potential spillover effects arising from firms' engagement in innovating firms (Nadiri, 1993). Finally, the models include time dummy variables (year 2001 is the base year), regional dummy variables (17 regions, the base category is Andalusia), and industry dummy variables (19 industries based on the 3-digit NACE classification; the base category is the manufacture of fabricated metal products) (see Table A2 for the list of manufacturing sectors).

\section{Estimation strategy}

Our estimation strategy encompasses a dynamic panel analysis, which, besides controlling for unobserved heterogeneity and a potential reverse causality, allows modelling the persistence of innovation. More specifically, a dynamic specification accounts for state dependence process of the dependent variable, modelled as a $t-1$ lag (that is, $y_{i t-1}$ ). The $t-1$ lagged value of the dependent variable can be interpreted as true or genuine state dependence, that is, as the causal effect of innovation outcomes (patents, product and process innovation) in one period on their intensity (in case of patent counts) and propensity (in case of product and process innovations) in the subsequent period.

There are several arguments supporting persistence in innovation. The first relates to sunk costs (Sutton 1991), which influence investment in R\&D in the long term. Because R\&D is one of the key determinants of product innovation, continuous, long-run R\&D investment leads to continuous product innovation. The second argument is associated with the 'success breeds success' hypothesis (Flaig and Stadler 1994; Geroski et al. 1997). Namely, if product innovation is successfully introduced in one period, then firms gain market power, which increases the likelihood of future successful innovation. The third potential explanation for the persistence in innovation is dynamic increasing returns (Stiglitz 1987) and the cumulative nature of knowledge (Tavassoli and Karlsson 2015; Triguero and Córcoles 2013). 
Continuously innovating firms benefit from dynamic increasing returns as a result of learningby-doing and learning-to-learn effects, which increase a firm's knowledge base and technological capabilities (Clausen et al. 2011; Geroski et al. 1997; Haned et al. 2014).

Therefore, due to the autoregressive nature of the dependent variable, we employ a dynamic model and estimate Model 1 using a system Generalized Method of Moments (GMM) estimation procedure (Arellano and Bond, 1991). In addition, the system GMM allows us to control for unobserved heterogeneity and a potential simultaneity (reverse causality) between innovation outputs (patents and technological innovations) and innovation activities (internal and external $R \& D$ and cooperation). The method consists of taking the first differences of the model and then applying the GMM using the lagged levels of the endogenous variables as instrumental variables. Taking first differences controls for the unobserved fixed firm-effects. It is assumed that there is no serial correlation in the disturbance term and all the lagged variables can be used as valid instruments in the first difference equation (Roodman, 2009).

For Models 2 and 3, we employ a dynamic random effects probit model with unobserved heterogeneity. We assume that companies can be characterized by a latent product or process innovation propensity $\left(y_{i t}^{*}\right)$. Formally,

$$
y_{i t}^{*}=\gamma Z_{i t}+\alpha y_{i t-1}+c_{i}+u_{i t}
$$

In equation 2, the latent outcome variable $y_{i t}^{*}$ captures the probabilities of introducing product or process innovations in a firm $i(i=1, \ldots, N)$ in period $t$ as a function of a set of timevarying explanatory variables $Z$ it that are considered strictly exogenous, conditional on the unit-specific unobserved effect $c_{i}$, while $u_{i t}$ is an idiosyncratic error term (Grotti and Cutuli, 2018). The coefficient $\alpha$ captures the degree of true or genuine state dependence of product or process innovation. That it, $\alpha$ measures the extent to which engaging in product or process innovation in period $t-1$ increases or decreases the likelihood of current product or process innovation (in period $t$ ). Furthermore, we assume $y_{i t}=I\left(y_{i t}^{*}>0\right)$, that is, binary indicator functions that are 1 if the latent propensity is positive and 0 otherwise.

As in most studies that use longitudinal data, our panel is also affected by the initial condition problem. Namely, we do not have information on the companies since their creation, but only for a limited period of time. Firms could have introduced product and process innovations prior to our sample period. In order to account for the problem of initial conditions, we follow the proposal by Wooldridge (2005) presented in Equation 3: 


$$
c_{i}=\alpha_{0}+\alpha_{1} y_{i 0}+\alpha_{2} \bar{Z}_{i}+\alpha_{3} Z_{i 0}+\varepsilon_{i}
$$

The unobserved specific effects $c_{i}$ are estimated conditional on the dependent variable in the initial period $\left(y_{i 0}\right)$, the initial values of all time-varying covariates $\left(Z_{i 0}\right)$ and the withinfirm averages of the explanatory variables $\left(\bar{Z}_{i}\right)$, where the averages are based on all periods $t=0, \ldots, T . \varepsilon_{i}$ is a firm-specific time-constant error term, normally distributed with mean 0 and variance $\sigma_{\varepsilon}^{2}$ (Grotti and Cutuli, 2018).

\section{Results and Discussion}

The pairwise correlation coefficients are presented in Table A3. The correlation between in-house and external $R \& D$ is positive and weak $(0.14)$, hinting at the possibility that they could be complementary R\&D activities (Schmiedeberg, 2008). Other coefficients exhibit low or moderate correlations. In addition, we computed the variance inflation factors (VIFs). The average VIF value is 1.67 , while the maximum value is 3.1 , implying no issues with multicollinearity given that all VIFs are below 10 (Cohen et al., 2003).

Table 1 shows results for all three models. As the effects of the variable of interest on innovation outputs might not be contemporaneous, they are included in the model with a lag $(t-1)$. Model 1 (with patent counts as the dependent variable) is estimated using a Generalised Method of Moments (GMM). A finite sample Windermeijer (2005) correction to the two-step covariance matrix is applied, which makes estimation efficient and robust to heteroskedasticity and cross-correlation. GMM estimation is particularly appropriate for panel models, because this approach enables us to address the possibility that R\&D expenditure, firm size and market share are potentially endogenous without recourse to "external" instruments.

\section{Table 1. Estimations of the models.}

\begin{tabular}{|c|c|c|c|}
\hline Independent variables & Model 1 & Model 2 & Model 3 \\
\hline & $\begin{array}{c}\text { Product } \\
\text { innovation } \\
(\text { GMM } \\
\text { estimator) } \\
\end{array}$ & $\begin{array}{c}\text { Product } \\
\text { innovation } \\
\text { (dynamic RE } \\
\text { probit model) } \\
\end{array}$ & $\begin{array}{c}\text { Process } \\
\text { innovation } \\
\text { (dynamic RE } \\
\text { probit model) } \\
\end{array}$ \\
\hline Patent count $t_{t-1}$ & $\begin{array}{c}0.322 * * * \\
(0.090)\end{array}$ & & \\
\hline Product innovation $_{\mathrm{t}-1}$ & & $\begin{array}{c}1.266 * * * \\
(0.070)\end{array}$ & \\
\hline Process innovation $_{\mathrm{t}-1}$ & & & $\begin{array}{c}1.177 * * * \\
(0.064)\end{array}$ \\
\hline Internal $R \& D_{t-1}$ & $\begin{array}{c}-1.861 * * \\
(0.856)\end{array}$ & $\begin{array}{c}0.029 \\
(0.074)\end{array}$ & $\begin{array}{c}-0.01623 \\
(0.067)\end{array}$ \\
\hline Internal $R \& D_{t-1}^{2}$ & $0.307 * * *$ & 0.00004 & -0.00227 \\
\hline
\end{tabular}




\begin{tabular}{|c|c|c|c|}
\hline \multirow{3}{*}{ External $\mathrm{R} \& \mathrm{D}_{\mathrm{t}-1}$} & $(0.111)$ & $(0.003)$ & $(0.003)$ \\
\hline & 0.286 & -0.011 & 0.00776 \\
\hline & $(1.130)$ & $(0.025)$ & $(0.023)$ \\
\hline \multirow[t]{2}{*}{ External $R \& D_{t-1}^{2}$} & $0.193 * *$ & -0.004 & -0.04058 \\
\hline & $(0.080)$ & $(0.074)$ & $(0.068)$ \\
\hline \multirow[t]{2}{*}{ Coop $_{\mathrm{t}-1}$} & $24.245^{* *}$ & 0.244 & -0.21698 \\
\hline & $(10.072)$ & $(0.327)$ & $(0.304)$ \\
\hline \multirow[t]{2}{*}{$\operatorname{Coop}_{r-1}^{2}$} & -0.008 & -0.022 & 0.02040 \\
\hline & $(0.405)$ & $(0.030)$ & $(0.028)$ \\
\hline \multirow{2}{*}{ Internal $R \& D_{t-1} *$ External $R \& D_{t-1}$} & $-0.197 *$ & 0.002 & 0.00009 \\
\hline & $(0.106)$ & $(0.002)$ & $(0.002)$ \\
\hline \multirow[t]{2}{*}{ Internal $\mathrm{R} \& \mathrm{D}_{\mathrm{t}-1} *$ Coop $_{\mathrm{t}-1}$} & $-1.943 * *$ & -0.006 & 0.01033 \\
\hline & $(0.827)$ & $(0.026)$ & $(0.024)$ \\
\hline \multirow[t]{2}{*}{ External R\&D $\mathrm{D}_{\mathrm{t}-1} * \operatorname{Coop}_{\mathrm{t}-1}$} & $-2.233 * *$ & -0.003 & 0.00389 \\
\hline & $(0.954)$ & $(0.005)$ & $(0.005)$ \\
\hline \multirow[t]{2}{*}{ Internal $\mathrm{R} \& \mathrm{D}_{\mathrm{t}-1} *$ External $\mathrm{R} \& \mathrm{D}_{\mathrm{t}-1} *$ Coop $_{\mathrm{t}-1}$} & $0.172 * *$ & 0.001 & -0.00117 \\
\hline & $(0.078)$ & $(0.002)$ & $(0.002)$ \\
\hline \multirow[t]{2}{*}{ Export $_{t}$} & -0.829 & -0.227 & -0.053 \\
\hline & $(1.530)$ & $(0.302)$ & $(0.276)$ \\
\hline \multirow[t]{2}{*}{ Size $_{t}$} & 1.382 & 0.025 & $0.243 *$ \\
\hline & $(1.310)$ & $(0.158)$ & $(0.148)$ \\
\hline \multirow[t]{2}{*}{ Market share $_{\mathrm{t}}$} & -0.109 & 0.002 & -0.004 \\
\hline & $(0.071)$ & $(0.003)$ & $(0.003)$ \\
\hline \multirow[t]{2}{*}{ Participation $_{t}$} & $2.919 * *$ & 0.002 & 0.069 \\
\hline & $(1.460)$ & $(0.075)$ & $(0.069)$ \\
\hline \multirow[t]{2}{*}{$\mathrm{Age}_{\mathrm{t}}$} & -1.047 & 0.052 & -0.069 \\
\hline & $(0.830)$ & $(0.189)$ & $(0.204)$ \\
\hline \multirow[t]{2}{*}{$\mathrm{R} \& \mathrm{D}$ department $\mathrm{t}_{\mathrm{t}}$} & -0.470 & $0.316 * * *$ & $0.147 * *$ \\
\hline & $(0.574)$ & $(0.069)$ & $(0.062)$ \\
\hline \multirow[t]{2}{*}{ Foreign capital $_{t}$} & $-0.022 *$ & 0.0003 & -0.003 \\
\hline & $(0.012)$ & $(0.002)$ & $(0.002)$ \\
\hline \multirow[t]{2}{*}{ Constant } & $-26.089 * *$ & -30.585 & -0.887 \\
\hline & $(11.842)$ & $(32.088)$ & $(0.677)$ \\
\hline Log likelihood & & -1880.176 & -2043.231 \\
\hline Wald $\chi^{2}$ test & & $1030.66 * * *$ & $957.62 * * *$ \\
\hline Number of instruments & 246 & & \\
\hline $\operatorname{AR}(1)$ (no serial correlation in $1^{\text {st }}$ difference) & $\mathrm{p}=0.070$ & & \\
\hline $\begin{array}{l}\operatorname{AR}(2) \text { (no serial correlation in } 2^{\text {nd }} \\
\text { difference) }\end{array}$ & $\mathrm{p}=0.382$ & & \\
\hline Hansen (robust) test for instrument validity & $\mathrm{p}=0.380$ & & \\
\hline No of observations & 5,585 & 4,088 & 4,088 \\
\hline
\end{tabular}

Notes: $* * * \mathrm{p}<0.01, * * \mathrm{p}<0.05, * \mathrm{p}<0.10$. In Model 1, robust standard errors in parentheses. Time dummy variables included (the base year category is 2001). Industry dummy variables included (19 dummies, the base industry category is manufacture of fabricated metal products). Region dummies included (17 dummies, the base category is Andalusia).

To identify the nature of relationships between internal and external $R \& D$ in influencing innovation outputs in firms that engage in cooperation and those that do not, the coefficients on the three-way interactions are estimated. The only statistically significant coefficient $(\mathrm{p}<0.05)$ is estimated in Model 1 , while we do not find a conditional effect of cooperation on joint impact of external and internal $R \& D$ on either product or process innovation. Therefore, further in the text, we only interpret the coefficient on the three-way interaction from Model 1. Due to a nonlinear structure of the model, an interactive effect cannot 
be interpreted based on the estimated coefficient, but is given by the cross-partial derivative of innovation output with respect to both internal and external R\&D.

Considering issues about interpretation of interaction terms in non-linear models raised in the literature ( $\mathrm{Ai}$ and Norton, 2003), we follow a suggestion in the literature and present the results graphically (Aiken et al., 1991; Green, 2010). Green (2010) suggest that interaction effect should be interpreted as the change in the distance between sets of predicted probabilities. Since there is no theoretically suggested level of internal R\&D which would be of a particular interest, for the sake of presentational convenience, we follow the proposition by Aiken et al. (1991) and present marginal effects at low and high levels of a moderator variable (i.e. internal $R \& D$ ). Accordingly, one standard deviation below the mean represents a low level and one standard deviation above the mean marks a high level of internal R\&D. Figure 1 below shows the predicted probabilities of innovative performance at these two values of internal $R \& D$ and for all values of cooperative ties in the sample.

Figure 1. The moderating effect of cooperation breadth and internal R\&D on the relationship between external $R \& D$ and innovative performance for Model 1.

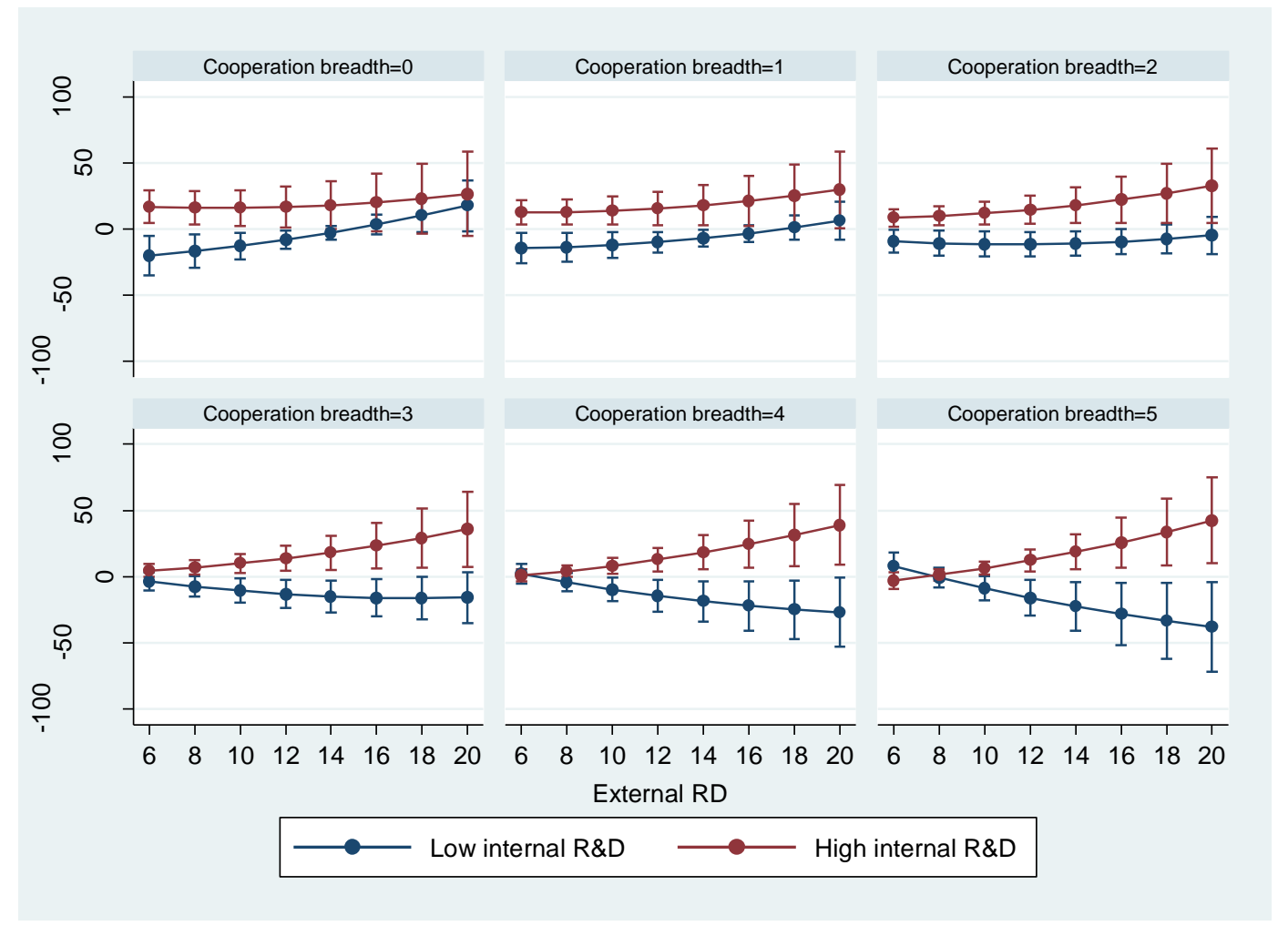

The results indicate that the joint impact of internal and external R\&D is determined by the number of cooperative partners. Figure 1 shows that there is a higher probability that 
increasing investment in external $R \& D$ will results in a larger number of patents at high levels of internal R\&D, but not at lower levels (i.e. there is complementarity between internal and external R\&D). This effect is particularly pertinent to firms with a large number of cooperative ties (more than two). When firms cooperate with a small number of partners (up to two), the high-low internal $R \& D$ curves tend to converge as external $R \& D$ increases, suggesting that the causal effect of external $R \& D$ on the number of patents is not conditional on internal $R \& D$. However, as the number of cooperative ties increases, the high-low internal R\&D curves tends to diverge with higher levels of external R\&D. In particular, the causal effect of external $R \& D$ on the number of patents is positive at high levels of internal $R \& D$, while it turns negative at low levels of internal R\&D. That is, a two-way interaction between internal and external $R \& D$ varies conditional on the number of partners, which is an indication that there is a three-way interaction between internal $\mathrm{R} \& \mathrm{D}$, external $\mathrm{R} \& \mathrm{D}$ and cooperation breadth. This finding provides support for Hla, which is consistent with Beneito (2006), who also found complementarity between contracted and internal R\&D in their influence on patent applications using a sample of Spanish firms, although without considering a moderating role of cooperation breadth.

Concerning control variables in Model 1, we found a positive and significant effect of participation in technologically innovative firms $(\mathrm{p}<0.05)$ and a negative and marginally significant effect of foreign capital $(\mathrm{p}<0.10)$. In relation to the latter, Díaz-Díaz et al. (2008) report a non-linear impact of foreign ownership in Spanish firms. In particular, they report a U-shaped relationship, such that foreign ownership initially has a negative effect on innovation performance, but after a certain threshold (57.22\%), the impact becomes positive. As can be seen in Table A2, the average participation of foreign capital in our sample is $29.43 \%$, which is almost a half of the threshold reported in Díaz-Díaz et al. (2008). Our result and the argument brought forward in Díaz-Díaz et al. (2008) would imply that foreign shareholders might foster the environment conducive to innovation only at a higher level of foreign ownership. Other control variables do not exhibit statistically significant effects.

Looking at the persistence in patent counts, the coefficient on the lagged dependent variable is positive and significant $(\beta=0.32 ; \mathrm{p}<0.05)$, implying true state dependence in the number of patent applications. That is, we find evidence of the causal effect of the number of patents in one period on their number in the subsequent period. Finally, a short note on the satisfactory diagnostics tests for Model 1. The Wald test indicates the joint significance, hence explanatory power, of the variables. The validity of the instruments for the lagged dependent variable and the variables treated as endogenous (internal $R \& D$, external $R \& D$, cooperation 
breadth, firm size and market share) is not rejected by: the $\mathrm{m} 1$ and $\mathrm{m} 2$ tests (i.e. the AR tests for, respectively, first- and second- order serial correlation in the first-differenced residuals) and the heteroskedasticity-robust Hansen test.

Now we turn our attention to Model 2 and 3 in which technological, product and process, innovations are the dependent variables. The probability of both types of technological innovations increases in firms with $R \& D$ departments $(p<0.01$ for product innovation and $\mathrm{p}<0.10$ for process innovation). The latter result reiterates the importance of absorptive capacity for innovative output. In addition, firm size is marginally significant $(p<0.10)$ in the case of process innovation (Model 3), hinting at the possibility that larger firms could be more likely to introduce process innovation than their smaller counterparts. Finally, the coefficients on both lagged dependent variables are positive and highly statistically significant $(\mathrm{p}<0.01)$, implying true state dependence for both product and process innovations. ${ }^{6}$ That is, we find evidence of the causal effect of the propensity to technological innovation in one period on its propensity in the subsequent period. The average marginal effects show that introducing product or process innovation in one period in itself increases the likelihood of introducing the same type of innovation in the subsequent period by $65 \%$ and $70 \%$ respectively. ${ }^{7}$

In summary, the first distinct finding is in relation to the difference between patent counts and technological product and process innovations. Among all three models, the effect of internal $R \& D$-external $R \& D$ interaction in predicting innovation output is moderated by the level of cooperation breadth only when innovation output is measured by the patent counts. ${ }^{8}$ The return on external R\&D increases with internal R\&D suggesting complementarity between these two innovation activities, while the association diminishes as firms engage with more cooperative partners making no difference of the increasing external $R \& D$ on the number of patents between low and high level of external $R \& D$ for a sufficiently large number of cooperative partners. The second finding points out to the evidence which is common to both product and process innovations (Models 2 and 3 respectively). Namely, our findings show that the joint impact of internal and external R\&D activities does not exhibit significantly different effect on product and process innovations conditional on the number of cooperative partners. The third finding is in relation to persistence of innovation. Our results suggest a

\footnotetext{
${ }^{6}$ In contrast to true state dependence, spurious persistence occurs when observed and unobserved firm characteristics that persist over time affect the likelihood of innovation output in the subsequent period.

${ }^{7}$ The difference between average marginal effects for product and process innovation is not statically significant at any conventional level.

${ }^{8}$ As a robustness check, we estimated a model with both concurrent and lagged effects of the variables of interest. The results are qualitatively the same as in the models reported in the study. The results are available on request.
} 
higher persistence of technological innovation compared to patent counts, which is consistent with conjectures in other studies (e.g. Clausen et al., 2011; Crespi and Scellato, 2015, Haned et al., 2014). Likewise, our results show persistence of both product and process innovations, which again corroborate previous empirical evidence (Clausen et al., 2011; Ganter and Hecker, 2013; Tavassoli and Karlsson, 2015). Moreover, our results suggest that the mean duration of persistence in both types of innovations is three years (2.9 years for product innovation and 3.4 years for process innovation).

Reflecting on theoretical considerations about the expected joint effects of innovation activities on different types of innovation output, our empirical findings are consistent with theoretical arguments in relation to patent applications and process innovation. First, qualitatively different results for patent counts relative to technological product and process innovations might result from a heterogeneous nature of $R \& D$ activities itself. That is, patents are mainly the result of research activities of $R \& D$ while product and process innovations are a result of development activities of $R \& D$. Furthermore, tacit knowledge is more pertinent to technological product and process product innovation than to patents. Contrary to positive effects noted in the theoretical section above, it might limit firms' absorptive capacity and reduce intended knowledge spillovers.

\section{Conclusions}

Our study provides insights into the relationship between internal $\mathrm{R} \& \mathrm{D}$ and external knowledge sources in Spanish manufacturing firms. In particular, we explore synergistic effects between internal and external $R \& D$ activities conditional on cooperation breadth while taking into account non-linearity of each innovation activity. Our empirical strategy encompasses several desirable features. First, by analysing longitudinal data, the study controls for unobserved heterogeneity, which is the major impediment in empirical studies on complementarity (Vega-Jurado et al., 2009). Second, measuring internal and external R\&D activities as continuous constructs enables us to capture the effect of scale of these activities, and not only whether firms engage in R\&D activities, which is the case when binary measures are utilized. Third, a dynamic panel analysis allows us to take into account persistence of innovation outputs, whereby true state dependence refers to the causal effect of innovation in one period on its occurrence in the subsequent period. In this way, finding from our study contribute to two streams of research: i) potential synergistic effects between internal and external innovation activities; and ii) persistence of innovation. 
The results for all three relationships vary depending on how innovation output is measured. When focused on the number of patents, the joint effect of external and internal $\mathrm{R} \& \mathrm{D}$ is conditional on the number of cooperative ties, while we do not find this conditionality for product and process innovations. In the context of Spanish firms, our findings are in line with previous studies. Concerning patent applications, Beneito (2006) reported complementarity between internal and external R\&D activities. With regards to product innovation, Vega-Jurado et al. (2009) found no evidence of either complementarity or substitutability between internal and external R\&D in the cross-section analysis using Spanish PITEC data.

Our results could be explained from the perspective of the degree of innovativeness of innovation outputs. Namely, in this context, innovation activities can be categorized into radical or incremental (although we do not have variables in the data to be able to make this distinction). If we assume that majority of product and process innovations are incremental in the Spanish context, given its long-standing position as a Moderate innovator country ${ }^{9}$, then our results imply that in the case of more radical innovation (i.e. patents, according to e.g. Beneito, 2016, who argues that firms apply for patents to protect their more radical product innovations), firms have large enough absorptive capacity to successfully exploit knowledge from both external R\&D sourcing and collaboration with different partners. Thus, these firms will repeat the benefits of complementary, synergistic, effects from internal and external innovation activities. This corroborates our empirical findings for patent counts as well as the argument brought forward in Forés and Camisón (2016), who argue that the degree of innovativeness depends on the size of the knowledge base and on the diversity of knowledge sources. More specifically, the larger the knowledge base is and the broader the cooperative network is, the more likely is that a firm will engage in radical innovation.

In contrast, if majority of product and process innovations are of incremental nature, then firms with weaker absorptive capacity will mainly introduce this type of innovation (Forés and Camisón, 2016). For these firms, due to their weak absorptive capacity, benefits of synergistic effects from internal and external innovation activities are offset by costs of acquiring and assimilating external knowledge, thus making the overall effect on product and process innovation insignificant. The same argument is brought forward in the German context, in which Schmiedeberg (2008) found no joint impact of internal and external R\&D and argued

\footnotetext{
${ }^{9}$ Following the Innovation Scoreboard, countries in this group have innovation performance below of the EU27 average. Spain belongs to this group according to all published Innovation Scoreboard reports from 2007 to 2018 (see http://ec.europa.eu/growth/industry/innovation/facts-figures/scoreboards_en).
} 
that this was due to German firms mostly introducing incremental innovation. Given that two studies on countries at significantly different levels of innovation performance, according to the European Scoreboard (one for Germany, which consistently belongs to the Innovation leaders country group, and our study for Spain) report the same findings, could indicate that one of the key aspects of future studies on this topic is to incorporate the degree of innovativeness when exploiting joint effects of innovation activities.

Another potential explanation of our findings is in relation to internal $R \& D$ as a measure of absorptive capacity. The literature recognizes that other innovation activities, besides internal $\mathrm{R} \& \mathrm{D}$, are also the determinants of firms' absorptive capacity, such as qualifications of the staff (Schmiedeberg, 2008), and training and design (Santamaría et al., 2009). Again, given the Spanish context, it could be that many innovative firms, especially those in low- and medium-technology industries, utilize non-R\&D activities to the same degree as internal R\&D or even larger (Forés and Camisón, 2016; Santamaría et al., 2009). This would suggest that future research might consider incorporating non-R\&D activities as an integral part of firms' absorptive capacity.

Besides investigating potential complementary effects of different innovation inputs, our study reports findings in relation to true state dependence of innovation outputs. In line with most previous studies, we report a larger persistence of technological innovations than patents. Moreover, both product and process innovations are highly path-dependent (introducing product or process innovation in one period increases the propensity of the same type of innovation in the subsequent period by $65 \%$ and $70 \%$ respectively).

Our findings infer some policy implications. A single argument brought forward in most empirical studies (Ebersberger and Herstad, 2011; Gonzáles et al., 2014; Hagedoorn and Wang, 2012; Serrano-Bedia et al., 2012; Vega-Jurado et al., 2009) is that internal R\&D capacity is critical for achieving complementary, synergistic effects from external knowledge sourcing (this is known as the absorptive capacity hypothesis). Given that Spain belongs to the Moderate innovators country group, absorptive capacity in Spanish firms is suboptimal in relation to technological aspects of innovation, thus suggesting a clear policy implication of providing public support aimed at strengthening firms' internal innovation capacity (Gonzáles et al., 2014). This corroborates Vega-Jurado et al. (2009), who note that policy makers in Spain and other countries at a similar level of innovation performance, should try to avoid the risk of overrating external technology sourcing and instead concentrate on promoting firms' absorptive capacity. Equally important, given that absorptive capacity is path-dependent (Cohen and Levinthal, 1990; Forés and Camisón, 2016), policy makers should be aware that 
enhancing firms' internal innovation capacity will have long-run effects on their innovation performance. Not only that absorptive capacity, as the key factor in firms' innovation performance is path-dependent, but also innovation outputs, in particular product and process innovations. This true state dependence is reported in our studies (the mean duration of persistence of product and process innovation is three years), as in most previous studies. This suggests that, by promoting firms' absorptive capacity, policy makers will, at the same time, promote the introduction of technological innovations in the medium run. In addition, the lack of evidence on complementarity in relation to technological aspects of innovation performance might suggest that public policies focusing on encouraging cooperation for innovation might not produce optimal results (Gonzáles et al., 2014), unless firms' absorptive capacity is large enough to successfully absorb and utilize external knowledge.

\section{Limitations and suggestions for future research}

Notwithstanding the novel features of our study, it also suffers from certain limitations that can provide avenues of further research. First, available data does not allow the distinction between radical and incremental product innovations. It could be the case that the joint impact of innovation activities varies depending on the degree of novelty of product innovation (see e.g. Jirjahn and Kraft, 2011). Second, most studies on complementarity in the innovation process either do not separately analyse large firms and small and medium-sized firms (SMEs) or only analyse large firms (e.g. Hagedoorn and Wang, 2012). Therefore, future studies could explore whether the same type of relationship between R\&D activities exists in SMEs as well as in large firms. Finally, future comparative studies between countries (for instance, as in Arvanitis et al., 2015) could reveal country-specific features of innovation processes (Schmiedeberg, 2008) or reasons behind heterogeneous innovation performance across countries (Krzeminska and Eckert, 2016). As noted above, Spain belongs to the group of Moderate innovators countries. With respect to the generalization of our findings, they might apply to other countries in this category (Croatia, Czech Republic, Greece, Hungary, Italy, Lithuania, Malta, Poland, Portugal, and Slovakia). That is, the results from our study could point to the nature of combined effects of innovation inputs on innovation performance in less innovative European countries. Moreover, as argued above, it could be that context dependency is more associated with the degree of innovativeness at the firm level, rather than a country's level of innovation performance. In this case, more studies exploring the issue of complementarity in the context of radical versus incremental innovations are needed. 


\section{References}

Arellano, M. and S. Bond. 1991. "Some tests of specification for panel data: Monte Carlo evidence and an application to employment equations." Review of Economic Studies 58: 277-297.

Arvanitis, S., B. Lokshin, P. Mohnen, and M. Woerter. 2015. "Impact of External Knowledge Acquisition Strategies on Innovation: A Comparative Study Based on Dutch and Swiss Panel Data." Review of Industrial Organization 46(4): 359-382.

Acs, Z. J. (Eds.) 1999. Are Small Firms Important? Their Role and Impact. Boston, London and Dordrecht: Kluwer Academic Publishers.

Acs, Z. J. and D. B. Audretsch.1991. Innovation and Technological Change. An International Comparison. Ann Arbor, MI: University of Michigan Press.

Aiken, L. S. and S. G. West.1991. Multiple Regression: Testing and Interpreting Interactions. Newbury Park, CA: Sage.

Antonelli, C. and C. Fassio. 2016. "The role of external knowledge(s) in the introduction of product and process innovations." $R \& D$ Management 46(S3): 979-991.

Barge-Gil A. and A. Lopez. 2013. "The complementarity effect of research and development on firm productivity." Applied Economics Letters 20(15): 1426-1430.

Barney, J. 1991. "Firm resources and sustained competitive advantage." Journal of Management 17(1): 99-120.

Becker, W. and J. Dietz. 2004). "R\&D cooperation and innovation activities of firms evidence for the German manufacturing industry." Research Policy 33(2): 209-523.

Beneito, P. 2006. "The innovative performance of in-house and contracted R\&D in terms of patents and utility models." Research Policy 35(4): 502-517.

Berchicci, L. 2013. "Towards an open R\&D system: Internal R\&D investment, external knowledge acquisition and innovative performance." Research Policy 42(1): 117-127.

Bester, C. A., and C. B. Hansen. 2016. "Grouped effects estimators in fixed effects models." Journal of Econometrics 190(1): 197-208.

Brambour, T., W. R. Clark, and M. Golder. 2006. "Understanding Interaction Models: Improving Empirical Analysis." Political Analysis 14(1): 63-82.

Caloghirou, Y., I. Kastelli and A. Tsakanikas. 2004. "Internal capabilities and external knowledge sources: complements or substitutes for innovative performance?" Technovation 24(1): 29-39.

Cameron, A. C. and P. K. Trivedi. 1986. "Econometric models based on count data: Comparisons and applications of some estimators and tests." Journal of Applied Econometrics 1(1): 29-53.

Cassiman, B., E. Golovko and E. Martinez-Ros. 2010. "Innovation, exports and productivity." International Journal of Industrial Organization 28(4): 372-376.

Cassiman, B., and R. Veugelers. 2006. "In Search of Complementarity in Innovation Strategy: Internal R\&D, Cooperation in R\&D and External Technology Acquisition." Management Science 52(1): 68-82.

Charbonneau, K. B. 2014. Multiple Fixed Effects in Binary Response Panel Data Models. Bank of Canada Working Paper/Document de travail 2014-17.

Chen, Y.-S., M.-J. J. Lin and C.-H. Chang. 2009. "The positive effects of relationship learning and absorptive capacity on innovation performance and competitive advantage in industrial markets." Industrial Marketing Management 38(2): 152-158.

Chen, Y., W. Vanhaverbeke and J. Du. 2016. "The interaction between internal R\&D and different types of external knowledge sourcing: an empirical study of Chinese innovative firms." R\&D Management 46(S3): 1006-1023. 
Chesbrough, H. 2003. Open innovation: The new imperative for creating and profiting from technology. Boston: Harvard Business School Press.

Choi, D., S. Lee and Y. Kim. 2012. "The complementarities and contextualities of corporate R\&D strategies: An empirical analysis of Korean manufacturing industry." Journal of Management and Organization 18(3): 311-333.

Clausen, T., M. Pohjola, K. Sapprasert, K. and B. Verspagen. 2011. "Innovation strategies as a source of persistent innovation." Industrial and Corporate Change 21(3), 553-585.

Cohen, W.M. and D.A. Levinthal. 1989. "Innovation and Learning: The Two Faces of R\&D.” The Economic Journal 99(397): 569-596.

Cohen, W. M. and D. A. Levinthal. 1990. "Absorptive Capacity: A New Perspective on Learning and Innovation." Administrative Science Quarterly 35(1): 128-152.

Cohen, W. M., and S. Klepper. 1996. "Firm size and the nature of innovation within industries: the case of process and product R\&D." The Review of Economics and Statistics 78(2): 232-243.

Cohen, P., J. Cohen, S. G. West and L. S. Aiken. 2003. Applied Multiple Regression/ Correlation Analysis for the Behavioral Science ( $3^{\text {rd }}$ ed.). Hillsdale, NJ: Lawrence Erlbaum Associates.

Crespi, F. and G. Scellato. 2015. Knowledge cumulability and path dependence in innovation persistence. In: Antonelli, C., Link, A. (Eds.), Routledge Handbook of the Economics of Knowledge. Routledge, New York, pp. 116-134.

Cruz-Cázares, C., C. Bayona-Sáez and T. García-Marco. 2013. "You can't manage right when you can't measure well: Technological innovation efficiency." Research Policy 42(6-7): 1239-1250.

Czarnitzki, D., W. Glänzel, and K. Hussinger. 2009. "Heterogeneity of patenting activity and its implications for scientific research." Research Policy 38(1): 26-34.

Czarnitzki, D. and C. Lopes-Bento. 2013. "Value for money? New microeconometric evidence on public R\&D grants in Flanders." Research Policy 42(1): 76-89.

Damanpour, F. and S. Gopalakrishnan. 2001. "The dynamics of the adoption of product and process innovations in organizations." Journal of Management Studies 38(1): 45-65.

Diaz, M. A. and R. Sanchez. 2008. "Firm size and productivity in Spain: a stochastic frontier analysis." Small Business Economics 30(3): 315-323.

Dyer, J.H. and H. Singh. 1998. "The relational view: Cooperative strategy and sources of interorganizational competitive advantage." Academy of Management Review 23(4): 660-679.

Ebersberger, B. and S. J. Herstad. 2011. "Product Innovation and the Complementarities of External Interfaces.” European Management Review 8(3): 117-135.

Ebersberger, B., C. Bloch, S. J. Herstad and E. van de Velde. 2012. "Open Innovation Practices and Their Effect on Innovation Performance." International Journal of Innovation \& Technology Management 9(6): 1-22.

Escribano, A., A. Fosfuri and J. A. Tribo. 2009. "Managing external knowledge flows: The moderating role of absorptive capacity." Research Policy 38(1): 96-105.

Ettlie, J. E. and E. M. Reza. 1992. "Organizational integration and process innovation." Academy of Management Journal 35(4): 795-827.

Fabrizio, K. R. 2009. "Absorptive capacity and the search for innovation.” Research Policy 38(2): 256-267.

Fang, C., J. Lee and M. A. Schilling. 2010. "Balancing exploration and exploitation through structural design: the isolation of subgroups and organizational learning." Organization Science 21(3): 625-642.

Faems, D., M. De Visser, P. Andries and B. Van Looy. 2010. “Technology alliance portfolio 
and financial performance: Value-enhancing and cost-increasing effects of open innovation." Journal of Product Innovation Management 27(6): 785-796.

Flaig, G. and M. Stadler. 1994. "Success breeds success: The dynamics of the innovation process." Empirical Economics 19(1): 55-68.

Forés, B. and Camisón, C. (2016). "Does incremental and radical innovation performance depend on different types of knowledge accumulation capabilities and organizational size?" Journal of Business Research 69: 831-848.

Ganter, A. and A. Hecker. 2013. "Persistence of innovation: Discriminating between types of innovation and sources of state dependence." Research Policy 42(8): 1431-1445.

Geroski, P.A., J. Reenen and C.F. Walters. 1997. "How persistently do firms innovate?" Research Policy 26: 33-48.

Gonzáles, X., J. Jaumandreu and C. Pazó. 2005. "Barriers to innovation and subsidy Effectiveness." RAND Journal of Economics 36(4): 930-950.

Gonzáles, X. and C. Pazó. 2008. "Do public subsidies stimulate private R\&D spending?" Research Policy 37(3): 371-389.

González, M.G., Tato M.G. and Soto, C.F. (2014). Complementarity between Internal R\&D and R\&D Cooperation in the Context of Spanish Technological Opportunities. Review of Business Management 16(53): 540-559.

Gopalakrishnan, S., P. Bierly and E. H. Kessler. 1999). "A reexamination of product and process innovations using a knowledge-based view.” Journal of High Technology Management Research 10(1): 147-166.

Greene, W. 2004. "The behavior of the fixed effects estimator in nonlinear models." Econometrics Journal 7(1): 98-119.

Griliches, Z., A. Pakes, and B. H. Hall. 1987. "The Value of Patents as Indicators of Inventive Activity." In Economic Policy and Technological Performance, edited by P. Dasgupta and P. Stoneman, 97-121. Cambridge: Cambridge University Press:

Grimpe C. and U. Kaiser. 2010. "Balancing Internal and External Knowledge Acquisition: The Gains and Pains from R\&D outsourcing." Journal of Management Studies 47(8): 1483-1509.

Grotti, R. and G. Cutuli. 2018. "XTPDYN: Stata module to estimate dynamic random effects probit model with unobserved heterogeneity," Statistical Software Components S458465, Boston College Department of Economics.

Hagedoorn, J. and N. Wang. 2012. "Is there complementarity or substitutability between internal and external R\&D strategies?" Research Policy 41(6): 1072-1083.

Haned, N., C. Mothe and T.U. Nguyen-Thi. 2014. "Firm persistence in technological innovation: The relevance of organizational innovation." Economics of Innovation and New Technology 23(5-6): 490-516.

Hausman, J., B. H. Hall and Z. Griliches. 1984. "Econometric models for count data with an application to the patents-R\&D relationship." Econometrica 52(4): 909-938.

He, Z.-L. and P.-K. Wong. 2004. "Exploration vs. Exploitation: An Empirical Test of the Ambidexterity Hypothesis." Organization Science 15(4): 481-494.

Hess, A. M. and F. T. Rothaermel. 2011. "When are assets complementary? Star scientists, strategic alliances, and innovation in the pharmaceutical industry." Strategic Management Journal 32(8): 895-909.

Hilbe, J.M. 2011. Negative Binomial Regression ( $2^{\text {nd }}$ ed.). Cambridge: Cambridge University Press. 
Hou, J. and P. Mohnen. 2013. "Complementarity between In-house R\&D and Technology Purchasing: Evidence from Chinese Manufacturing Firms." Oxford Development Studies 41(3): 343-371.

Jirjahn, U. and K. Kraft. 2011. "Do Spillovers Stimulate Incremental or Drastic Product Innovations? Evidence from German Establishment Data." Oxford Bulletin of Economics and Statistics 73(4): 509-538.

Katz, R. and T. J. Allen. 1982. "Investigating the not invented here syndrome: a look at the performance, tenure and communication patterns of $50 \mathrm{R} \& \mathrm{D}$ project groups." $R \& D$ Management 12(1): 7-19.

Kogut, B. and U. Zander. 1992. "Knowledge of the Firm, Combinative Capabilities, and the Replication of Technology." Organization Science 3(3): 383-397.

Krzeminska, A. and C. Eckert. 2016. "Complementarity of internal and external R\&D: is there a difference between product versus process innovations?" $R \& D$ Management 46(S3): 931-944.

Laursen, K. and A. Salter. 2006. "Open for Innovation: The role of openness in explaining innovative performance among UK manufacturing firms." Strategic Management Journal 27(2): 131-50.

Lokshin, B., R. Belderbos and M. Carree. 2008. "The Productivity Effects of Internal and External R\&D: Evidence from a Dynamic Panel Data Model." Oxford Bulletin of Economics and Statistics 70(3): 399-413.

Milgrom, P. and J. Roberts. 1995. "Complementarities and fit. Strategies, structure and organizational change in manufacturing." Journal of Accounting and Economics 19(23): 179-208.

Montoya, P., R. Zárate and L. Martín. 2007. "Does the Technological Sourcing Decision Matter? Evidence from Spanish Panel Data.” R\&D Management 37(2): 161-172.

Moorman, C. and R. J. Slotegraaf. 1999. "The contingency value of complementary capabilities in product development." Journal of Marketing Research 36(2): 239-257.

Mowery, D.C. 1983. "The relationship between intrafirm and contractual forms of industrial research in American manufacturing, 1900-1940.” Explorations in Economic History 20(4): 351-374.

Nadiri, I. 1993. "Innovations and Technological Spillovers.” NBER Working Paper Series Working Paper No 4423.

Neyman, J. and E. Scott. 1948. "Consistent estimates based on partially consistent observations." Econometrica 16(1): 1-32.

Nieto, M. J. and L. Santamaría. 2007. "The importance of diverse collaborative networks for the novelty of product innovation." Technovation 27(6): 367-377.

Pippel, G. and V. Seefeld. 2016. R\&D cooperation with scientific institutions: a difference-in-difference approach." Economics of Innovation and New Technology 25(5): 455-469.

Pisano, G. P. 1990. "The R\&D Boundaries of the Firm: An Empirical Analysis." Administrative Science Quarterly 35(1): 153-176.

Raymond, W., P.A. Mohnen, F. Palm and S.S. Van der Loeff. 2010. "Persistence of innovation in Dutch manufacturing: is it spurious?" Review of Economics and Statistics 92: 495504.

Reichstein, T. and A. Salter. 2006. "Investigating the sources of process innovation among UK manufacturing firms." Industrial and Corporate Change 15(4): 653-682.

Ritala, P. and P. Hurmelinna-Laukkanen. 2009. "What's in it for me? Creating and appropriating value in innovation-related coopetition." Technovation 29(12): 819-828.

Roodman, D., 2009. "How to do Xtabond2: An Introduction to Difference and System GMM 
in Stata." Stata Journal 9(1): 86-136.

Rothaermel, F. T. and A. M. Hess. 2007. "Building dynamic capabilities: Innovation driven by individual-, firm-, and network-level effects." Organization Science 18(6): 898921.

Santamaría. L., M. J. Nieto and A. Barge-Gil. 2009. "Beyond formal R\&D: Taking advantage of other sources of innovation in low- and medium-technology industries." Research Policy 38(3): 507-517.

Sapienza, A. M. and J. G. Lombardino. 2002. "Recognizing, appreciating, and capturing the tacit knowledge of R\&D scientists." Drug Development Research 57(2): 51-57.

Schmiedeberg C. 2008. "Complementarities of innovation activities: An empirical analysis of the German manufacturing sector." Research Policy 37(9): 1492-1503.

Selnes, F. and J. Sallis. 2003. "Promoting relationship learning." Journal of Marketing 67(3): 80-95.

Serrano-Bedia, A. M., M. C. López-Fernández and G. García-Piqueres. 2012.

"Complementarity between innovation activities and innovation performance:

Evidence from Spanish innovative firms.” Journal of Manufacturing Technology Management 23(5): 557-577.

Serrano-Bedia, A. M., M. C. López-Fernández and G. García-Piqueres. 2018. Complementarity between innovation knowledge sources: Does the innovation performance measure matter?" Business Research Quarterly 21: 53-67.

Stiglitz, J. 1987. "Learning to learn, localized learning and technological progress." In P. Dasgupta and P. Stoneman (Eds.), Economic Policy and Technological Performance (pp.125-153). Cambridge: Cambridge University Press.

Sutton, J. 1991. Sunk Costs and Market Structure. Cambridge, MA: MIT Press.

Tavassoli, S. and C. Karlsson 2015. Persistence of various types of innovation analyzed and explained. Research Policy 44(10): 1887-1901.

Topkis, D. M. 1978. "Minimizing a submodular function on a lattice." Operations Research 26(2): 305-321.

Triguero, Á. and D. Córcoles. 2013. "Understanding innovation: An analysis of persistence for Spanish manufacturing firms." Research Policy 42(2): 340-352.

Un, C.A., A. Cuervo-Cazurra and K. Asakawa. 2010. "R\&D Collaborations and Product Innovation." Journal of Product Innovation Management 27(5): 673-689.

Van Beers, C., and F. Zand. 2014. "R\&D Cooperation, Partner Diversity, and Innovation Performance: An Empirical Analysis." Journal of Product Innovation Management 31(2): 292-312.

Van de Vrande, V., J. P. J. de Jong, W. Vanhaverbeke and M. de Rochemont. 2009. "Open innovation in SMEs: Trends, motives and management challenges." Technovation 29(6-7): 423-437.

Vega-Jurado, J., A. Gutiérrez-Gracia, I. Fernández-de-Lucio and L. Manjarrés-Hendriquez. 2008. "The effect of external and internal factors on firms' product innovation." Research Policy 37(4): 616-632.

Vega-Jurado, J., A. Gutiérrez-Gracia, and I. Fernández-de-Lucio. 2009. "Does external knowledge sourcing matter for innovation? Evidence from the Spanish manufacturing industry." Industrial and Corporate Change 18(4): 637-670.

Verona, G. 1999. "A resource-based view of product development." Academy of Management Review 24(1): 132-142.

Weigelt, C. 2009. "The impact of outsourcing new technologies on integrative capabilities and performance." Strategic Management Journal 30(6): 595-616.

Weiss, P. 2003. "Adoption of product and process innovations in differentiated markets: the impact of competition." Review of Industrial Organization 23(3): 301-314. 
Williamson, O.E. 1985. The Economic Institutions of Capitalism. New York: Free Press.

Woerter, M. 2011. "Driving forces for research and development strategies: an empirical analysis based on firm-level panel data." Economics of Innovation and New Technology 20(7): 611-636.

Wong, P. K., L. Lee and M. D. Foo. 2008. "Occupational choice: the influence of product vs. process innovation." Small Business Economics 30(3): 267-281.

$\mathrm{Wu}$, J. 2014. "Cooperation with competitors and product innovation: Moderating effects of technological capability and alliances with universities." Industrial Marketing Management 43(2): 199-209.

Wooldridge, J.M. 2005. "Simple solutions to the initial conditions problem in dynamic, nonlinear panel data models with unobserved heterogeneity." Journal of Applied Econometrics 20: 39-54. 


\section{Appendix}

Table A1. Review of empirical studies on complementarity between internal and external R\&D activities.

\begin{tabular}{|c|c|c|c|c|c|c|}
\hline Study & $\begin{array}{l}\text { Innovation } \\
\text { output } \\
\text { indicator(s) }\end{array}$ & $\begin{array}{l}\text { Type(s) of } \\
\text { relationship }\end{array}$ & Country & $\begin{array}{c}\text { Measure of } \\
\text { innovation activity }\end{array}$ & Method & $\begin{array}{c}\text { Findings } \\
\text { (complementarity or substitution) }\end{array}$ \\
\hline Beneito (2006) & $\begin{array}{l}\text { - Patents } \\
\text { - Utility models }\end{array}$ & $\begin{array}{l}\text { Internal (in-house) } \\
\text { R\&D and contracted } \\
\text { R\&D }\end{array}$ & Spain & $\begin{array}{l}\text { Both measures are } \\
\text { continuous }\end{array}$ & $\begin{array}{l}\text { Negative } \\
\text { binomial panel } \\
\text { analysis }\end{array}$ & $\begin{array}{l}\text {-In patent model: complementarity } \\
\text {-In utility model: substitution }\end{array}$ \\
\hline $\begin{array}{l}\text { Cassiman and } \\
\text { Veugelers } \\
(2006)\end{array}$ & $\begin{array}{l}\text { - Innovative } \\
\text { sales }\end{array}$ & $\begin{array}{l}\text { Internal R\&D } \\
\text { (MAKE) and external } \\
\text { technology acquisition } \\
\text { (BUY) }\end{array}$ & Belgium & $\begin{array}{l}\text { Both MAKE and } \\
\text { BUY variables are } \\
\text { binary }\end{array}$ & $\begin{array}{l}\text { Cross section } \\
\text { analysis, two- } \\
\text { stage Heckman } \\
\text { model }\end{array}$ & Complementarity \\
\hline $\begin{array}{l}\text { Schmiedeberg } \\
(2008)\end{array}$ & $\begin{array}{l}\text { - Patents } \\
\text { (binary } \\
\text { indicator) } \\
\text { - Innovative } \\
\text { sales }\end{array}$ & $\begin{array}{l}\text { - Internal and external } \\
\text { R\&D } \\
\text { - Internal R\&D and } \\
\text { cooperation }\end{array}$ & Germany & $\begin{array}{l}\text { All three measures } \\
\text { (internal R\&D, } \\
\text { external R\&D, R\&D } \\
\text { cooperation) are } \\
\text { binary }\end{array}$ & $\begin{array}{l}\text { Cross section } \\
\text { analysis } \\
\text { - Tobit for } \\
\text { innovative sales } \\
\text { - Logit for } \\
\text { patents }\end{array}$ & $\begin{array}{l}\text { For patents: } \\
\text { - No significant effect between internal } \\
\text { and external R\&D } \\
\text { - Marginal complementarity between } \\
\text { internal R\&D and cooperation } \\
\text { For innovative sale: } \\
\text { - No significant relationships }\end{array}$ \\
\hline $\begin{array}{l}\text { Vega-Jurado et } \\
\text { al. }(2008)\end{array}$ & $\begin{array}{l}\text { - Product } \\
\text { innovation }\end{array}$ & $\begin{array}{l}\text { Internal R\&D and } \\
\text { cooperation breadth }\end{array}$ & Spain & $\begin{array}{l}\text { - Internal R\&D as a } \\
\text { continuous variable } \\
\text { (intensity) } \\
\text { - Cooperation breadth } \\
\text { as the number of } \\
\text { cooperative partners } \\
\end{array}$ & $\begin{array}{l}\text { Cross section } \\
\text { analysis, } \\
\text { multinomial } \\
\text { logistic model }\end{array}$ & $\begin{array}{l}\text { - Insignificant relationship between } \\
\text { internal R\&D and cooperation with } \\
\text { customers, suppliers and competitors } \\
\text { - Substitution between internal R\&D } \\
\text { and cooperation with consultants and } \\
\text { universities }\end{array}$ \\
\hline $\begin{array}{l}\text { Vega-Jurado et } \\
\text { al. (2009) }\end{array}$ & $\begin{array}{l}\text { - Product } \\
\text { innovation }\end{array}$ & $\begin{array}{l}\text { - Internal and external } \\
\text { R\&D } \\
\text { - Internal R\&D and } \\
\text { cooperation }\end{array}$ & Spain & $\begin{array}{l}\text { All three measures } \\
\text { (internal } R \& D, \\
\text { external } R \& D, R \& D \\
\text { cooperation) are } \\
\text { binary }\end{array}$ & $\begin{array}{l}\text { Cross section } \\
\text { analysis, second } \\
\text { stage Heckman } \\
\text { logit model }\end{array}$ & $\begin{array}{l}\text { - Insignificant relationship between } \\
\text { internal and external R\&D } \\
\text { - Insignificant relationship between } \\
\text { internal R\&D and cooperation }\end{array}$ \\
\hline $\begin{array}{l}\text { Grimpe and } \\
\text { Kaiser (2010) }\end{array}$ & $\begin{array}{l}\text { - Innovative } \\
\text { sales }\end{array}$ & $\begin{array}{l}\text { - Internal and external } \\
\text { R\&D } \\
\text { - External R\&D and } \\
\text { cooperation breadth }\end{array}$ & Germany & $\begin{array}{l}\text { Internal and external } \\
\text { R\&D as continuous } \\
\text { variables (intensity) } \\
\text { - Cooperation breadth } \\
\text { as the number of } \\
\text { cooperative partners }\end{array}$ & $\begin{array}{l}\text { Random effects } \\
\text { panel tobit model }\end{array}$ & $\begin{array}{l}\text { - Complementarity between internal and } \\
\text { external innovation activities } \\
\text { - Tipping point at high levels of external } \\
\text { R\&D }\end{array}$ \\
\hline
\end{tabular}




\begin{tabular}{|c|c|c|c|c|c|c|}
\hline & & & & & & $\begin{array}{l}\text { - Complementarity between external } \\
\text { R\&D and cooperation }\end{array}$ \\
\hline $\begin{array}{l}\text { Ebersberger } \\
\text { and Herstad } \\
(2011)\end{array}$ & $\begin{array}{l}\text { - Radical } \\
\text { innovation (new } \\
\text { to the market) }\end{array}$ & $\begin{array}{l}\text { - Internal R\&D and } \\
\text { cooperation } \\
\text { - External R\&D and } \\
\text { cooperation }\end{array}$ & Norway & $\begin{array}{l}\text { Internal and external } \\
\text { R\&D are continuous } \\
\text { variables (intensity) } \\
\text { - Cooperation is a } \\
\text { binary variable }\end{array}$ & $\begin{array}{l}\text { Cross section } \\
\text { analysis, probit } \\
\text { model }\end{array}$ & $\begin{array}{l}\text { - Complementarity between internal } \\
\text { R\&D and collaboration only if R\&D } \\
\text { intensity up to } 30 \% \\
\text { - Substitution between internal R\&D } \\
\text { and collaboration if R\&D intensity } \\
\text { above } 90 \% \\
\text { - Substitution between collaboration and } \\
\text { external R\&D }\end{array}$ \\
\hline $\begin{array}{l}\text { Choi et al. } \\
(2012)\end{array}$ & $\begin{array}{l}\text { - Innovative } \\
\text { sales }\end{array}$ & $\begin{array}{l}\text { - Internal and external } \\
\text { R\&D } \\
\text { - Internal R\&D and } \\
\text { cooperation } \\
\text { - External R\&D and } \\
\text { cooperation }\end{array}$ & South Korea & $\begin{array}{l}\text { - External R\&D is } \\
\text { continuous (intensity) } \\
\text { - Cooperation is a } \\
\text { binary indicator }\end{array}$ & $\begin{array}{l}\text { Cross section } \\
\text { analysis, } \\
\text { multinomial } \\
\text { logit-tobit model }\end{array}$ & $\begin{array}{l}\text { - Insignificant relationship between } \\
\text { internal and external } R \& D \\
\text { - Complementarity between internal } \\
\text { R\&D and cooperation } \\
\text { - Marginal substitution for external } \\
\text { R\&D and cooperation }\end{array}$ \\
\hline $\begin{array}{l}\text { Serrano-Bedia } \\
\text { et al. }(2012)\end{array}$ & $\begin{array}{l}\text { - Innovative } \\
\text { sales }\end{array}$ & $\begin{array}{l}\text { Three-way interaction } \\
\text { between internal } R \& D \text {, } \\
\text { external } R \& D \text { and } \\
\text { cooperation }\end{array}$ & Spain & $\begin{array}{l}\text { All three innovation } \\
\text { activities are binary } \\
\text { indicators }\end{array}$ & OLS estimation & $\begin{array}{l}\text { - Complementarity between all pair- } \\
\text { wise combinations (two-way } \\
\text { interactions) except for external R\&D } \\
\text { and cooperation } \\
\text { - Complementarity between all three } \\
\text { innovation activities }\end{array}$ \\
\hline $\begin{array}{l}\text { Hagedoorn and } \\
\text { Wang (2012) }\end{array}$ & - Patent count & $\begin{array}{l}\text { Internal and external } \\
\text { R\&D }\end{array}$ & $\begin{array}{l}\text { Pharma } \\
\text { firms }\end{array}$ & $\begin{array}{l}\text {-Internal R\&D } \\
\text { expenditures are a } \\
\text { continuous variable } \\
\text { - External R\&D is a } \\
\text { binary indicator }\end{array}$ & $\begin{array}{l}\text { Panel fixed } \\
\text { effects negative } \\
\text { binomial model }\end{array}$ & $\begin{array}{l}\text { Internal and external R\&D are } \\
\text { substitutes below the threshold level } \\
(1,400 \text { million dollars), while they are } \\
\text { complements above the threshold level. }\end{array}$ \\
\hline $\begin{array}{l}\text { Berchicci } \\
(2013)\end{array}$ & $\begin{array}{l}\text { - Innovative } \\
\text { sales }\end{array}$ & $\begin{array}{l}\text { Internal and external } \\
\text { R\&D }\end{array}$ & Italy & $\begin{array}{l}\text { - Internal } R \& D \text { is the } \\
\text { share of } R \& D \\
\text { personnel } \\
\text { - External R\&D is the } \\
\text { percentage of } \\
\text { outsourced R\&D }\end{array}$ & Panel tobit model & $\begin{array}{l}\text { - At lower level of internal R\&D, } \\
\text { internal and external R\&D are } \\
\text { complementary } \\
\text { - At higher level of internal R\&D, } \\
\text { internal and external R\&D are } \\
\text { substitutes }\end{array}$ \\
\hline $\begin{array}{l}\text { González et al. } \\
\text { (2014) }\end{array}$ & $\begin{array}{l}\text { - Innovative } \\
\text { sales }\end{array}$ & $\begin{array}{l}\text { Internal R\&D and } \\
\text { cooperation }\end{array}$ & Spain & $\begin{array}{l}\text { Both internal R\&D } \\
\text { and cooperation are } \\
\text { binary indicators }\end{array}$ & $\begin{array}{l}\text { Cross section } \\
\text { analysis, } \\
\text { Heckman two- } \\
\text { stage model }\end{array}$ & $\begin{array}{l}\text { - Substitution between internal R\&D } \\
\text { and collaboration }\end{array}$ \\
\hline
\end{tabular}




\begin{tabular}{|c|c|c|c|c|c|c|}
\hline $\begin{array}{l}\text { Gesing et al. } \\
(2015)\end{array}$ & $\begin{array}{l}\text { - Innovative } \\
\text { sales from } \\
\text { radical and } \\
\text { incremental } \\
\text { innovations }\end{array}$ & $\begin{array}{l}\text { Internal } R \& D \text { and } \\
\text { cooperation }\end{array}$ & Germany & $\begin{array}{l}\text {-Internal } R \& D \text { is a } \\
\text { continuous measure } \\
\text { (intensity) } \\
\text { - Cooperation is } \\
\text { binary }\end{array}$ & $\begin{array}{l}\text { Cross section } \\
\text { analysis, tobit } \\
\text { model }\end{array}$ & $\begin{array}{l}\text {-No significant effect between internal } \\
\text { R\&D and informal cooperation } \\
\text { - Substitution between internal R\&D } \\
\text { and hybrid and formal types of } \\
\text { cooperation }\end{array}$ \\
\hline $\begin{array}{l}\text { Arvanitis et al. } \\
(2015)\end{array}$ & $\begin{array}{l}\text { - Innovative } \\
\text { sales }\end{array}$ & $\begin{array}{l}\text { Three-way interaction } \\
\text { between internal, } \\
\text { external R\&D and } \\
\text { cooperation breadth }\end{array}$ & $\begin{array}{l}\text { Switzerland } \\
\text { and } \\
\text { Netherlands }\end{array}$ & $\begin{array}{l}\text { - Internal R\&D is a } \\
\text { continuous measure } \\
\text { (intensity) } \\
\text { - External R\&D is a } \\
\text { continuous measure } \\
\text { (intensity) } \\
\text { - Cooperation breadth } \\
\text { is the number of } \\
\text { cooperative partners }\end{array}$ & $\begin{array}{l}\text { Heckman two- } \\
\text { stage random } \\
\text { effect panel } \\
\text { model }\end{array}$ & $\begin{array}{l}\text { Switzerland: } \\
\text { - No significant joint effect of internal } \\
\text { R\&D, external R\&D and cooperation } \\
\text { Netherlands: } \\
\text { - Complementarity between internal } \\
\text { R\&D, external R\&D and cooperation }\end{array}$ \\
\hline $\begin{array}{l}\text { Krzeminska } \\
\text { and Eckert } \\
(2016)\end{array}$ & $\begin{array}{l}\text { - Innovative } \\
\text { sales } \\
\text { - Process } \\
\text { innovation } \\
\end{array}$ & $\begin{array}{l}\text { Internal and external } \\
\text { R\&D }\end{array}$ & Germany & $\begin{array}{l}\text { Measures of both } \\
\text { internal and external } \\
\text { R\&D are binary }\end{array}$ & $\begin{array}{l}\text { Cross section } \\
\text { analysis, ordinal } \\
\text { regression }\end{array}$ & $\begin{array}{l}\text { - Complementarity between internal and } \\
\text { external R\&D on innovative sales } \\
\text { - Insignificant joint effect on process } \\
\text { innovation }\end{array}$ \\
\hline $\begin{array}{l}\text { Antonelli and } \\
\text { Fassio (2016) }\end{array}$ & $\begin{array}{l}\text { - Product } \\
\text { innovation } \\
\text { - Process } \\
\text { innovation }\end{array}$ & $\begin{array}{l}\text { Industry-specific total } \\
\text { R\&D and openness } \\
\text { (the firm-specific } \\
\text { propensity to engage in } \\
\text { external R\&D) }\end{array}$ & $\begin{array}{l}\text { Belgium, } \\
\text { Czech } \\
\text { Republic, } \\
\text { Germany, } \\
\text { Italy, } \\
\text { Norway and } \\
\text { Spain } \\
\end{array}$ & $\begin{array}{l}\text {-Industry-specific } \\
\text { total R\&D is a } \\
\text { continuous measure } \\
\text {-Openness is proxied } \\
\text { by a binary variable }\end{array}$ & $\begin{array}{l}\text { Cross section } \\
\text { analysis, probit } \\
\text { model }\end{array}$ & $\begin{array}{l}\text {-Complementarity between industry- } \\
\text { specific total R\&D and openness on } \\
\text { both product and process innovations }\end{array}$ \\
\hline $\begin{array}{l}\text { Chen et al. } \\
(2016)\end{array}$ & $\begin{array}{l}\text {-Innovative } \\
\text { sales }\end{array}$ & $\begin{array}{l}\text { Two-way interactions } \\
\text { between internal R\&D } \\
\text { and four external } \\
\text { knowledge sources: } \\
\text { value-chain partners, } \\
\text { horizontal connections, } \\
\text { science-based partners, } \\
\text { and technology service } \\
\text { providers }\end{array}$ & $\begin{array}{l}\text { China - } \\
\text { Zhejiang } \\
\text { province }\end{array}$ & $\begin{array}{l}\text {-Internal R\&D is a } \\
\text { continuous measure } \\
\text {-Sources of external } \\
\text { knowledge are } \\
\text { derived from the } \\
\text { factor analysis }\end{array}$ & $\begin{array}{l}\text { Cross section } \\
\text { analysis, OLS } \\
\text { model }\end{array}$ & $\begin{array}{l}\text {-Complementarity between: } \\
\text { internal R\&D and value-chain partners } \\
\text { internal R\&D and horizontal } \\
\text { connections } \\
\text { internal R\&D and technology service } \\
\text { providers } \\
\text {-Firms with higher levels of internal } \\
\text { R\&D benefit more from external } \\
\text { knowledge sources }\end{array}$ \\
\hline $\begin{array}{l}\text { Serrano-Bedia } \\
\text { et al. (2018) }\end{array}$ & $\begin{array}{l}\text {-Product } \\
\text { innovation } \\
\text {-Process } \\
\text { innovation }\end{array}$ & $\begin{array}{l}\text {-Internal and external } \\
\text { knowledge sources and } \\
\text { cooperation }\end{array}$ & $\begin{array}{l}\text { Spain } \\
\text { (Community } \\
\text { Innovation }\end{array}$ & $\begin{array}{l}\text { All three activities } \\
\text { are binary indicators }\end{array}$ & $\begin{array}{l}\text { Cross section } \\
\text { analysis, probit } \\
\text { model }\end{array}$ & $\begin{array}{l}\text {-Substitutability between internal } \\
\text { knowledge sources and cooperation in } \\
\text { product and process innovations }\end{array}$ \\
\hline
\end{tabular}




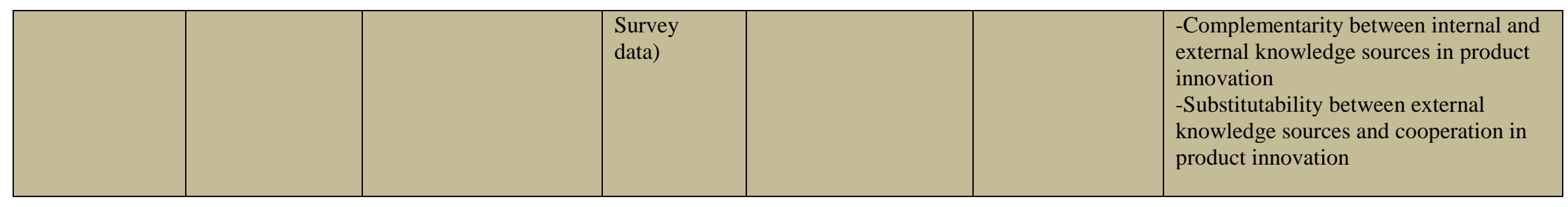


Table A2. Variable description and summary statistics.

\begin{tabular}{|c|c|c|c|}
\hline Variables & Definition & $\begin{array}{c}\text { Mean } \\
\text { (standard } \\
\text { deviation) }\end{array}$ & Median \\
\hline \multicolumn{3}{|c|}{ Dependent variable } & \\
\hline Patents & $\begin{array}{l}\text { Number of patents that a firm filled in } \\
\text { Spain and abroad }\end{array}$ & $\begin{array}{c}1.297 \\
(10.340)\end{array}$ & 0.000 \\
\hline Product innovation & $\begin{array}{l}\mathrm{DV}=1 \text { if the firm introduced product } \\
\text { innovation; zero otherwise }\end{array}$ & $\begin{array}{c}0.443 \\
(0.497) \\
\end{array}$ & 0.000 \\
\hline Process innovation & $\begin{array}{l}\mathrm{DV}=1 \text { if the firm introduced process } \\
\text { innovation; zero otherwise }\end{array}$ & $\begin{array}{c}0.525 \\
(0.499)\end{array}$ & 1.000 \\
\hline \multicolumn{3}{|c|}{ Variables of interest } & \\
\hline Internal R\&D & $\begin{array}{l}\text { Internal R\&D expenditures in natural } \\
\text { logarithm }\end{array}$ & $\begin{array}{l}10.578 \\
(4.744)\end{array}$ & 12.059 \\
\hline External R\&D & $\begin{array}{l}\text { External R\&D expenditures in natural } \\
\text { logarithm }\end{array}$ & $\begin{array}{c}7.732 \\
(5.825)\end{array}$ & 10.239 \\
\hline \multirow[t]{2}{*}{ Coop } & $\begin{array}{l}\text { Categorical variable, ranging from } 0 \text { to } 5 \text {, } \\
\text { equal to the number of cooperative ties: } \\
\text { cooperation with customers, suppliers, } \\
\text { competitors, HEIs and joint ventures. }\end{array}$ & $\begin{array}{l}2.675 \\
(1.184)\end{array}$ & 3.000 \\
\hline & Control variables & & \\
\hline Export & Ratio of export value divided by sales & $\begin{array}{c}0.826 \\
(0.277)\end{array}$ & 0.925 \\
\hline Participation & $\begin{array}{l}\mathrm{DV}=1 \text { if a firm participates in } \\
\text { technologically innovative firm; zero } \\
\text { otherwise }\end{array}$ & $\begin{array}{c}0.402 \\
(0.490)\end{array}$ & 0.000 \\
\hline Size & $\begin{array}{l}\text { Firm size measured as the number of } \\
\text { employees (in natural logarithm) }\end{array}$ & $\begin{array}{c}5.265 \\
(1.311)\end{array}$ & 5.412 \\
\hline Market share & $\begin{array}{l}\text { Weighted sum of the firm's market shares in } \\
\text { the markets in which it sells its products; } \\
\text { the variable ranges from } 0 \text { to } 100 \%\end{array}$ & $\begin{array}{c}13.818 \\
(18.842)\end{array}$ & 6.000 \\
\hline Age & Firm age (in natural logarithm) & $\begin{array}{l}3.653 \\
(0.499)\end{array}$ & 3.680 \\
\hline R\&D department & $\begin{array}{l}\mathrm{DV}=1 \text { if a firm has an R\&D department; } \\
\text { zero otherwise }\end{array}$ & $\begin{array}{c}0.605 \\
(0.488)\end{array}$ & 1.000 \\
\hline Foreign capital & $\begin{array}{l}\text { Percentage of direct or indirect participation } \\
\text { of foreign capital in a firm's capital }\end{array}$ & $\begin{array}{c}29.429 \\
(44.229)\end{array}$ & 0.000 \\
\hline \multicolumn{3}{|c|}{ Industry dummy variables (DVs) } & \\
\hline Meat products & $\begin{array}{l}\mathrm{DV}=1 \text { if the firm is operating in } \\
\text { manufacture of meat products; zero } \\
\text { otherwise }\end{array}$ & $\begin{array}{c}0.020 \\
(0.140)\end{array}$ & 0.000 \\
\hline Food and tobacco & $\begin{array}{l}\mathrm{DV}=1 \text { if the firm is operating in } \\
\text { manufacture of food and tobacco; zero } \\
\text { otherwise }\end{array}$ & $\begin{array}{l}0.078 \\
(0.269)\end{array}$ & 0.000 \\
\hline Beverage & $\begin{array}{l}\mathrm{DV}=1 \text { if the firm is operating in } \\
\text { manufacture of beverage; zero otherwise }\end{array}$ & $\begin{array}{c}0.023 \\
(0.148)\end{array}$ & 0.000 \\
\hline Textiles and clothing & $\begin{array}{l}\mathrm{DV}=1 \text { if the firm is operating in } \\
\text { manufacture of textiles and clothing; zero } \\
\text { otherwise }\end{array}$ & $\begin{array}{l}0.053 \\
(0.224)\end{array}$ & 0.000 \\
\hline $\begin{array}{l}\text { Leather, fur and } \\
\text { footwear }\end{array}$ & $\begin{array}{l}\mathrm{DV}=1 \text { if the firm is operating in } \\
\text { manufacture of leather, fur and footwear; } \\
\text { zero otherwise }\end{array}$ & $\begin{array}{l}0.0168 \\
(0.129)\end{array}$ & 0.000 \\
\hline
\end{tabular}




\begin{tabular}{|c|c|c|c|}
\hline Timber & $\begin{array}{l}\mathrm{DV}=1 \text { if the firm is operating in } \\
\text { manufacture of timber; zero otherwise }\end{array}$ & $\begin{array}{c}0.019 \\
(0.139)\end{array}$ & 0.000 \\
\hline Paper & $\begin{array}{l}\mathrm{DV}=1 \text { if the firm is operating in } \\
\text { manufacture of paper; zero otherwise }\end{array}$ & $\begin{array}{c}0.022 \\
(0.146) \\
\end{array}$ & 0.000 \\
\hline Printing & $\begin{array}{l}\mathrm{DV}=1 \text { if the firm is operating in } \\
\text { manufacture of printing; zero otherwise }\end{array}$ & $\begin{array}{c}0.011 \\
(0.104)\end{array}$ & 0.000 \\
\hline $\begin{array}{l}\text { Chemicals and } \\
\text { pharmaceuticals }\end{array}$ & $\begin{array}{l}\mathrm{DV}=1 \text { if the firm is operating in } \\
\text { manufacture of chemicals and } \\
\text { pharmaceuticals; zero otherwise }\end{array}$ & $\begin{array}{c}0.129 \\
(0.335)\end{array}$ & 0.000 \\
\hline $\begin{array}{l}\text { Plastic and rubber } \\
\text { products }\end{array}$ & $\begin{array}{l}\mathrm{DV}=1 \text { if the firm is operating in } \\
\text { manufacture of plastic and rubber products; } \\
\text { zero otherwise }\end{array}$ & $\begin{array}{c}0.060 \\
(0.238)\end{array}$ & 0.000 \\
\hline $\begin{array}{l}\text { Nonmetal mineral } \\
\text { products }\end{array}$ & $\begin{array}{l}\mathrm{DV}=1 \text { if the firm is operating in } \\
\text { manufacture of nonmetal mineral products; } \\
\text { zero otherwise }\end{array}$ & $\begin{array}{c}0.053 \\
(0.225)\end{array}$ & 0.000 \\
\hline Basic metal products & $\begin{array}{l}\mathrm{DV}=1 \text { if the firm is operating in } \\
\text { manufacture of basic metal products; zero } \\
\text { otherwise }\end{array}$ & $\begin{array}{c}0.052 \\
(0.223) \\
\end{array}$ & 0.000 \\
\hline $\begin{array}{l}\text { Fabricated metal } \\
\text { products }\end{array}$ & $\begin{array}{l}\mathrm{DV}=1 \text { if the firm is operating in } \\
\text { manufacture of fabricated metal products; } \\
\text { zero otherwise }\end{array}$ & $\begin{array}{c}0.087 \\
(0.281)\end{array}$ & 0.000 \\
\hline $\begin{array}{l}\text { Machinery and } \\
\text { equipment }\end{array}$ & $\begin{array}{l}\mathrm{DV}=1 \text { if the firm is operating in } \\
\text { manufacture of machinery and equipment; } \\
\text { zero otherwise }\end{array}$ & $\begin{array}{c}0.092 \\
(0.288)\end{array}$ & 0.000 \\
\hline $\begin{array}{l}\text { Computer products, } \\
\text { electronics and } \\
\text { optical }\end{array}$ & $\begin{array}{l}\mathrm{DV}=1 \text { if the firm is operating in } \\
\text { manufacture of computer products, } \\
\text { electronics and optical; zero otherwise }\end{array}$ & $\begin{array}{c}0.042 \\
(0.2004)\end{array}$ & 0.000 \\
\hline $\begin{array}{l}\text { Electric materials } \\
\text { and accessories }\end{array}$ & $\begin{array}{l}\mathrm{DV}=1 \text { if the firm is operating in } \\
\text { manufacture of electric materials and } \\
\text { accessories; zero otherwise }\end{array}$ & $\begin{array}{c}0.066 \\
(0.249)\end{array}$ & 0.000 \\
\hline $\begin{array}{l}\text { Vehicles and } \\
\text { accessories }\end{array}$ & $\begin{array}{l}\mathrm{DV}=1 \text { if the firm is operating in } \\
\text { manufacture of vehicles and accessories; } \\
\text { zero otherwise }\end{array}$ & $\begin{array}{c}0.094 \\
(0.291)\end{array}$ & 0.000 \\
\hline $\begin{array}{l}\text { Other transport } \\
\text { equipment }\end{array}$ & $\begin{array}{l}\mathrm{DV}=1 \text { if the firm is operating in } \\
\text { manufacture of other transport equipment; } \\
\text { zero otherwise }\end{array}$ & $\begin{array}{c}0.033 \\
(0.179)\end{array}$ & 0.000 \\
\hline Furniture & $\begin{array}{l}\mathrm{DV}=1 \text { if the firm is operating in } \\
\text { manufacture of furniture; zero otherwise }\end{array}$ & $\begin{array}{c}0.039 \\
(0.193)\end{array}$ & 0.000 \\
\hline Other manufacturing & $\begin{array}{l}\mathrm{DV}=1 \text { if the firm is operating in other } \\
\text { manufacturing industries; zero otherwise }\end{array}$ & $\begin{array}{c}0.008 \\
(0.090)\end{array}$ & 0.000 \\
\hline
\end{tabular}


Table A3. Correlation matrix

\begin{tabular}{|c|c|c|c|c|c|c|c|c|c|c|}
\hline & 1. & 2. & 3. & 4. & 5. & 6. & 7. & 8. & 9. & 10. \\
\hline 1. Internal $\mathrm{R} \& \mathrm{D}_{\mathrm{t}-1}$ & 1.000 & & & & & & & & & \\
\hline 2. External $R \& D_{t-1}$ & $0.140 * * *$ & 1.000 & & & & & & & & \\
\hline 3. Coop $_{\mathrm{t}-1}$ & $0.4305^{* * *}$ & $0.333 * * *$ & 1.000 & & & & & & & \\
\hline 4. Export & $0.201 * * *$ & $0.157 * * *$ & $0.158 * * *$ & 1.000 & & & & & & \\
\hline 5. Participation & $-0.178 * * *$ & $-0.177 * * *$ & $-0.172 * * *$ & $-0.234 * * *$ & 1.000 & & & & & \\
\hline 6. Size & $0.336 * * *$ & $0.287 * * *$ & $0.267 * * *$ & $0.312 * * *$ & $-0.507 * * *$ & 1.000 & & & & \\
\hline 7. Market share & $0.084 * * *$ & $0.038 * * *$ & $0.044 * * *$ & $0.027 * *$ & $-0.159 * * *$ & $0.219 * * *$ & 1.000 & & & \\
\hline 8. Age & $0.145 * * *$ & $0.067 * * *$ & $0.056 * * *$ & $0.150 * * *$ & $-0.039 * * *$ & $0.215 * * *$ & $0.048^{* * *}$ & 1.000 & & \\
\hline $\begin{array}{l}\text { 9. R\&D } \\
\text { department }\end{array}$ & $0.379 * * *$ & $0.112 * * *$ & $0.292 * * *$ & $0.104 * * *$ & $-0.122 * * *$ & $0.200 * * *$ & $0.068^{* * *}$ & $0.103 * * *$ & 1.000 & \\
\hline 10. Foreign capital & $0.101 * * *$ & $0.064 * * *$ & $0.106 * * *$ & $0.201 * * *$ & $-0.393 * * *$ & $0.393 * * *$ & $0.115^{* * *}$ & $0.085^{* * *}$ & $0.051 * * *$ & 1.000 \\
\hline
\end{tabular}

Notes: *** $p<0.01, * * p<0.05, * p<0.10$. 